\title{
Medievalista
}

\section{Para o estudo de um direito senhorial nas terras medievais de Alcobaça: o montado dos porco}

A contribution to the study of a manorial right in the medieval lands of Alcobaça: the montado dos porcos

\section{Iria Gonçalves}

\section{(2) OpenEdition}

\section{Journals}

\section{Edição electrónica}

URL: http://journals.openedition.org/medievalista/1310

DOI: $10.4000 /$ medievalista.1310

ISSN: 1646-740X

\section{Editora}

Instituto de Estudos Medievais - FCSH-UNL

\section{Refêrencia eletrónica}

Iria Gonçalves, "Para o estudo de um direito senhorial nas terras medievais de Alcobaça: o montado dos porco », Medievalista [Online], 22 | 2017, posto online no dia 01 dezembro 2017, consultado no dia 20 abril 2019. URL : http://journals.openedition.org/medievalista/1310 ; DOI : 10.4000/ medievalista. 1310

\section{(C) IEM}


Título / Title: Para o estudo de um direito senhorial nas terras medievais de Alcobaça: o montado dos porcos / A contribution to the study of a manorial right in the medieval lands of Alcobaça: the montado dos porcos Autor(es) / Author(s): Iria Gonçalves Universidade / University: Universidade Nova de Lisboa Faculdade e Departamento / Unidade de Investigação - Faculty and Department / Research Center: Faculdade de Ciências Sociais e Humanas, Departamento de História / Instituto de Estudos Medievais

Código Postal / Postcode: 1069-061

Cidade / City: Lisboa

País / Country: Portugal

Email Institucional / Institutional email: iem.geral@fcsh.unl.pt

Fonte: Medievalista [Em linha]. Direc. Bernardo Vasconcelos e Sousa. Lisboa: IEM.

Disponível em:

http://www2.fcsh.unl.pt/iem/medievalista/MEDIEVALISTA22/goncalves2202.html ISSN: 1646-740X

Data recepção do artigo / Received for publication: 27 de Março de 2017 


\section{Resumo}

Entre os direitos senhoriais cobrados nos coutos do mosteiro de Alcobaça encontravamse aqueles que podiam ser cobrados pela fruição dos incultos, nomeadamente dos espaços florestais, com toda a gama de potencialidades que tais espaços continham e podiam oferecer. Entre essas contribuições contava-se, como uma das mais importantes, o pagamento do montado, que em Alcobaça impendia apenas sobre a pastagem dos porcos nas matas senhoriais, durante o período da montanheira, entre Setembro e Janeiro. Omisso nos forais concedidos pelo mosteiro às vilas dos coutos, o tributo só se desenvolveria por meados do século XIV, dando origem a longo conflito com as comunidades locais, apenas resolvido pelos forais novos do século XVI.

Palavras-chave: Alcobaça; direitos senhoriais; matas; montado; porcos.

\section{Abstract}

Among the manorial rights collected by the monastery of Alcobaça were those that could be gathered upon the fruition of the uncultivated lands, particularly the forests, given the range of the potential that such areas had and could offer. Among those rights, one of the most important was the payment of the montado, which in Alcobaça impended only upon the pasture of pigs in the manor woods during the period known as montanheira, between September and January. Omitted in the primitive charters granted by the monastery to its villages, this tax was developed just by the middle of the fourteenth century, giving rise to a long conflict with the local communities, only solved by the new charters of the sixteenth century.

Keywords: Alcobaça; manorial rights; forests; montado; pigs. 


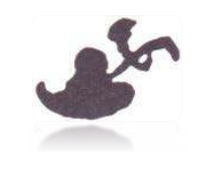

Para o estudo de um direito senhorial nas terras medievais de Alcobaça: o montado dos porcos / A contribution to the study of a manorial right in the medieval lands of Alcobaça: the montado dos porcos Iria Gonçalves

Com extensos domínios sobre os quais se exercia a jurisdição do D. Abade de Alcobaça e, para lá deles, com grande multiplicidade de terras de cultivo e de imóveis construídos que lhe pagavam foro ${ }^{1}$, era aquele um dos maiores potentados eclesiásticos do País ${ }^{2}$, gozando de imunidades e privilégios que não raro podiam ser lesivos para o interesse das populações que habitavam as suas terras, sobretudo quando, ao menos no entender dessas mesmas populações, o senhor exorbitava das suas prerrogativas. Mas elas eram actuantes, de diversa índole, e permitiam-lhe cobrar, dentro das terras que senhoriava, multiplicidade de direitos.

De entre aqueles que geralmente eram atributo do senhor jurisdicional contavam-se, ao menos durante a Plena e sobretudo a Baixa Idade Média, os que podiam ser cobrados pela fruição dos incultos, nomeadamente dos espaços florestais, com toda a gama de

\footnotetext{
${ }^{1}$ Veja-se GONÇALVES, Iria - O património do mosteiro de Alcobaça nos séculos XIV e XV. Lisboa: FCSH-UNL, 1989.

${ }^{2}$ Se analisarmos a lista dos rendimentos eclesiásticos do país elaborada em 1320, aquando da cedência feita pelo papa em favor de D. Dinis, do dízimo de todos aqueles rendimentos, durante três anos, verificamos que o mosteiro de Alcobaça foi avaliado em dezoito mil libras (ALMEIDA, Fortunato de -

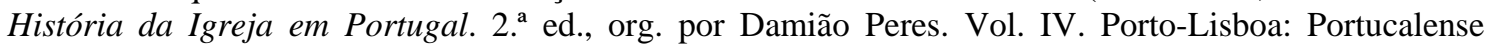
Editora, 1971, p. 129). Se percorrermos toda essa lista (ALMEIDA, Fortunato de - História da Igreja..., vol. IV, pp. 92-143), verificamos que, para lá dos Mestres das Ordens Militares e de alguns bispos arcebispo de Braga e bispos de Lisboa, Coimbra e Évora, aliás, todos eles com os rendimentos divididos entre mesa episcopal e mesa capitular, para lá de alguns apréstamos -, só o mosteiro de Santa Cruz de Coimbra foi avaliado em maior quantia, dividida, também ela, entre mesa prioral e mesa conventual. A generalidade dos demais mosteiros, e outras instituições religiosas, mesmo as mais ricas, ficaram todas a uma enorme distância.
} 
potencialidades que tais espaços continham e podiam oferecer. Entre essas contribuições contava-se, como uma das mais importantes, o pagamento do montado, que em Alcobaça, de acordo com a documentação disponível, impendia apenas sobre a pastagem dos porcos nas matas senhoriais, durante o período da montanheira.

Porque ele deixou, nas terras de Alcobaça, uma soma de informações mais abundante e rica do que a generalidade dos demais direitos, afigura-se-me que talvez mereça análise com algum detalhe.

\section{I - O montado}

Na sequência de Julius Klein ${ }^{3}$, parece consensual afirmar-se que a origem do montado se encontra nas multas resultantes de intrusões indevidas nos montes coutados e de danos causados pelos gados nas suas deslocações entre pastagens, como forma de compensação por esses mesmos danos ${ }^{4}$. E, na verdade, não deviam ser raros nem essas intrusões nem os prejuízos causados, sobretudo nas terras de cultivo, pelos rebanhos transumantes nas suas tão longas deslocações entre as pastagens de Verão e de Inverno. Por isso ele, esse direito, existiu em todas as regiões em que se praticava a transumância ${ }^{5}$.

Todavia, desde relativamente cedo, o montado começou a transformar-se num encargo fixo, devido pelo acesso às pastagens e seu consumo ${ }^{6}$. Alguns investigadores espanhóis apontam como o momento documentado a partir do qual aquela punção começou a ser

\footnotetext{
${ }^{3}$ KLEIN, Julius - La Mesta. Estudio de historia económica espanhola. 1273-1836. [3. ${ }^{\text {a }}$ ed.]. Madrid: Alianza Editorial, 1981, pp. 169-170.

${ }^{4}$ Já foram muitos os investigadores que deixaram expressa a sua aceitação. Entre outros, podem ver-se: TRINDADE, Maria José Lagos - "A vida pastoril e o pastoreio em Portugal nos séculos XII a XVI". in Estudos de história medieval e outros. Lisboa: História \& Crítica, 1981, p. 34; ARGENTE DEL CASTILLO OCAÑA, Cármen - La ganadería medieval andaluza. Siglos XIII-XVI (Reinos de Jaén y Córdoba). Vol. II. Jaén: Diputacón Provincial de Jaén, 1991, p. 629; CARMONA RUIZ, María Antonia La ganadería en el reino de Sevilla durante la Baja Edad Media. Sevilha: Diputación de Sevilla, 1998, p. 422.

${ }^{5}$ TRINDADE, Maria José Lagos - “A vida pastoril...," p. 34.

${ }^{6}$ KLEIN, Julius - La Mesta..., p. 170; CASTRO, Armando de - A evolução económica de Portugal dos séculos XII a XV. Vol. I. Lisboa: Portugália Editora, 1964, p. 161; CASTRO, Armando - "Montado". in SERRÃO, Joel (dir.) - Dicionário de História de Portugal. Vol. III. Lisboa: Iniciativas Editoriais, 1968, p. 100; DURAND, Robert - Les campagnes portugaises Entre Douro et Tage aux XII et XIII siècles. Paris: Centre Culturel Portugais, 1982, p. 151; CONDE, Manuel Sílvio Alves - Uma paisagem humanizada. O Médio Tejo nos finais da Idade Média. Vol. I. Cascais: Patrimonia, 2000, p. 260; CARMONA RUIZ, María Antonia - La ganadería, p. 422.
} 
arrecadada nesse conceito, o início do século $\mathrm{XI}^{7}$ ou o final da centúria seguinte ${ }^{8}$, de acordo com a região por eles estudada. Entre nós, pelo menos o foral de Évora de 1166 mostra-nos já o montado a ser exigido como uma quantia fixa ${ }^{9}$, o que, naturalmente, se torna incompatível com o pagamento de multas, por natureza variável com a prática, ou não, de danos a ressarcir e com a maior ou menor gravidade desses danos. No entanto, se a quantia fixa foi a forma de solvência do montado recolhida por aquele foral e também por outros do mesmo século e de início de Duzentos, ela vinha já, sem dúvida, a ser prática corrente desde época anterior. Isto é, durante todo o século XII e por certo como herança leonesa, o montado era já, no espaço em que ao tempo se inscrevia o reino de Portugal, um direito a pagar pelo consumo dos pastos, no que se refere aos gados alheios ao respectivo concelho. É certo que em alguns forais ${ }^{10}$ não se encontra averbado esse direito, mas sim em outros, precisamente aqueles que Alexandre Herculano classificou como pertencentes aos tipos de Ávila e Salamanca ${ }^{11}$. Talvez a sublinhar a ideia de herança leonesa. O que, porém, não impedia a sua cobrança em outros concelhos em cujos forais a contribuição não tivesse sido expressamente registada $^{12}$.

Mas se, por um lado, só os gados de fora do concelho pagavam montado - o que significa, obviamente, que os dos vizinhos estavam isentos - por outro só as espécies bovina e ovina - talvez ovicaprina ${ }^{13}$ - se encontravam contempladas naquela e em outra

\footnotetext{
${ }^{7}$ FRÍAS ZURITA, Victor - "El medio natural en una sociedad señorializada: composición, explotación y apropriación del inculto en la Catalunya del Noreste (siglos X-XIII)". in CLEMENTE RAMOS, Julián (ed.) - El medio natural en la España medieval. Actas del I congreso de ecohistoria e historia medieval. Cáceres: Universidad de Extremadura, 2001, p. 289.

${ }^{8}$ ARGENTE DEL CASTILLO OCAÑA, Carmen - La ganadería medieval andaluza..., vol. II, p. 629 inclina-se para os finais do século XII no que respeita à Andaluzia.

${ }^{9}$ TRINDADE, Maria José Lagos - "A vida pastoril e o pastoreio...”, p. 34.

${ }^{10}$ Aqueles que Alexandre HERCULANO classificou como sendo do tipo de Santarém (História de Portugal desde o começo da monarquia até ao fim do reinado de Afonso III. Ed. crítica de José MATTOSO, vol. IV. Lisboa: Livraria Bertrand, 1980, p. 540).

${ }^{11}$ HERCULANO, Alexandre - História de Portugal..., vol. IV, pp. 541-542. Também BARROS, Henrique da Gama - História da administração pública em Portugal nos seculos XII a XV. $2^{\mathrm{a}}$ ed. org. por Torquato de Sousa SOARES, t. IX. Lisboa: Livraria Sá da Costa, 1950, pp. 187-188.

${ }^{12}$ HERCULANO, Alexandre - História de Portugal..., vol. IV, p. 540.

${ }^{13}$ Sendo a espécie caprina ainda mais devastadora do que a ovina, na medida em que qualquer pasto lhe agrada e é capaz de o consumir até à exaustão, ao menos aparentemente não faz muito sentido que este gado estivesse isento da contribuição enquanto os ovinos eram tributados. Talvez porque o facto realmente significativo era a transumância e esta era especificamente praticada por ovinos, em rebanhos constituídos por vários milhares de animais deslocando-se através de longas distâncias e percorrendo assim os territórios de muitos concelhos fosse o que sobretudo causava grandes desgastes nas ervas e por vezes grandes prejuízos; talvez porque os rebanhos dos vizinhos, como os dos concelhos próximos que
} 
documentação, sendo obrigatório o pagamento de uma vaca por manada e quatro carneiros por rebanho ${ }^{14}$, sem que a composição dessas manadas e rebanhos fosse especificada. O que, naturalmente, tornava o pagamento da prestação tanto menos gravoso quanto maiores fossem os conjuntos desses animais. E de uma maneira geral eram aquelas as únicas espécies obrigadas a pagar montado ${ }^{15}$.

Assim sendo, os restantes animais ditos domésticos estavam isentos da punção e em alguns casos ficaram especificamente arredados dela - e isso importa para a análise que vai seguir-se - tanto o gado suíno como o cavalar ${ }^{16}$. O que faz bastante sentido. Sendo ambas as espécies menos depredatórias, menos numerosas e fazendo, em regra, na procura de pastagem, apenas deslocações de curto raio ${ }^{17}$, eram ao mesmo tempo, cada uma na sua medida, espécies de grande utilidade e apreço: estes, os animais por excelência nobres, sobretudo os que acompanhavam o cavaleiro na guerra e em todas as suas outras façanhas, mas também que serviam nos transportes e em outras actividades; aqueles com uma utilização que, na Idade Média, não conhecia igual, no que se refere ao fornecimento de carne. Nas terras de Alcobaça é o montado dos porcos, a pagar pelos vizinhos dos respectivos concelhos e de forma bem onerosa, o que encontramos em causa.

faziam apenas deslocações de curto raio, embora em geral mistos de ovelhas e cabras eram, de forma muito significativa, preferentemente integrados por ovinos, os caprinos, tão minoritários, pudessem, no contexto, ser esquecidos. Aliás o pagamento seria sempre feito em carneiros, os animais preferidos, tanto pela sua lã como pela sua carne, considerada, esta, superior à das demais espécies do rebanho. Era o que, na verdade, importava. Os caprinos podiam, no caso, ser negligenciados.

${ }^{14}$ Quantitativos que, averiguados por Alexandre HERCULANO (História de Portugal..., vol. IV, pp. 539-543) e repetidos por Henrique da Gama BARROS (Historia da administração publica em Portugal..., t. IX, pp. 187-192), têm voltado a ser referidos por quantos, entre nós, se debruçaram sobre o assunto. Vejam-se, entre outros: CASTRO, Armando - A evolução económica de Portugal..., vol. I, p. 181; CASTRO, Armando de - "Montado", p. 100; DURAND, Robert - Les campagnes portugaises..., p. 399; TRINDADE, Maria José Lagos - “A vida pastoril e o pastoreio...”, p. 61.

15 Para além da documentação foraleira a que acima fiz referência, um conjunto de documentos recolhidos nos restos que nos ficaram do que foi a chancelaria de D. Afonso III e que nos veiculavam aquela informação da mesma forma e com os mesmos quantitativos de pagamento, mostra bem a generalidade da ocorrência: CHANCELARIA DE D. AFONSO III. Ed. Leontina Ventura e António Resende de Oliveira, liv. I, vol. 1. Coimbra: Imprensa da Universidade de Coimbra, 2006, pp. 261-264.

${ }^{16}$ Vejam-se, como exemplos, os documentos citados na nota anterior.

17 Martín Gutiérrez, estudando assuntos próximos deste aqui tratado fala em deslocações de varas de porcos durante três ou quatro dias até ao local de pastagem, onde permaneceriam durante algum tempo. Veja-se MARTÍN GUTIÉRREZ, Emilio - Paisajes, ganadería y medio ambiente en las comarcas gaditanas. Siglos XIII al XVI. Cadiz: Universidad de Cadiz - Servicio de Publicaciones, 2015, p. 79. Pode ver-se também CABRERA MUÑOZ, Emilio - "El bosque, el monte y su aprovechamiento en la España del Sur durante la Baja Edad Media". in PÉREZ-EMBID, Javier (ed.) - La Andalucía medieval. Actas "I Jornadas de historia rural y medio ambiente" (Almonte, 23-25 Maio 2000). Huelva: Universidad de Huelva - Servicio de Publicaciones, 2002, p. 257. 


\section{II - O porco}

A Idade Média criava os seus animais, em primeiro lugar, para deles obter produtos e serviços e só quando começavam a tornar-se menos rendosos e eventualmente quando já velhos - e era o caso, sobre todos os outros, dos bois de lavoura - se sacrificavam para a obtenção de carne. Não assim o porco. Este era o único animal criado exclusivamente para servir a alimentação humana e nesse capítulo ele era insubstituível ${ }^{18}$ - uma “impressionante reserva de carne”, como já foi classificado ${ }^{19}$. Uma carne que, além do mais, era a que melhor correspondia aos processos de conservação que a Idade Média manipulava, o que a mantinha, assim, em boas condições de consumo durante todo o ano. Para isso, as suas carnes precisavam ser bem acondicionadas, pelo que, nos dias subsequentes à matança, então, como ainda em tempos bem próximos de nós, elas eram preparadas por meio da salga, da fumagem, do seu envolvimento na gordura derretida do próprio animal, após prévio branqueamento nessa mesma gordura ou em outra, pela confecção de enchidos, eles próprios também fumados. Nada, neste animal, se desperdiçava. E ele transformava-se, por aqueles processos, no mais abundante aprovisionamento de carne que a generalidade das famílias, e sobretudo as menos possidentes, dispunham durante todo o ano ${ }^{20}$.

\footnotetext{
${ }^{18}$ É este um facto reconhecido por numerosos investigadores e para todo o percurso da Idade Média. Podem ver-se, a título de exemplo: MONTANARI, Massimo - "Gli animali e l'alimentazione umana". in L'uomo di fronte al mondo animale nell'Alto Medioevo. XXXI Settimani di studi del Centro Italiano di Studi sull' Alto Medioevo. Tomo I. Spoleto: Centro italiano di studi sull'alto medioevo, 1985, p. 623; MONTANARI, Massimo - Alimentazione e cultura nel Medioevo. Roma / Bari: Editiri Laterza, 1988, p. 37; REDON, Odile - "Les usages de la viande en Toscanie au XVI siècle". in Manger et boire au Moyen Âge. Actes du colloque de Nice (15-17 octobre 1982). T. 2 - Cuisine, manières de table, régimes alimentaires. Nice: Publications de la Faculté des Lettres et de Sciences Humaines de Nice, 1984, p. 122; GONÇALVES, Iria - "A alimentação". in MATTOSO, José (dir.) - História da vida privada em Portugal. Vol. I - A Idade Média. Coord. por Bernardo Vasconcelos e SOUSA. Lisboa: Temas e Debates - Círculo de Leitores, 2010, p. 230.

${ }_{19}$ MONTANARI, Massimo - "Estruturas de produção e sistemas alimentares". in MONTANARI, Massimo; FLANDRIN, Jean-Louis (dir.) - História da alimentação.Vol. 1 - Dos primórdios à Idade Média. Trad. de Maria da Graça Pinhão. Lisboa: Terramar, 1998, p. 252.

${ }^{20}$ Era assim em toda a Europa e testemunhos provenientes dos mais diversos lugares provam isso mesmo. Para não sair do espaço geográfico em que nos inserimos poderei citar: CHARBONNIER, Pierre - Une autre France. La seigneurie rurale en Basse Auvergne du XIV au XVI siècle. Vol. I e II. ClermontFerrand: Publications de l'Institut d'Études du Massif Centrale - Faculté des Lettres et Sciences Humaines de l'Université de Clermond-Ferrand, 1980, p. 184; DÉMIANS D'ARCHIMBAUD, Gabrielle - Les fouilles de Rougiers (Var). Contribution à l'archéologie de l'habitat rural médiéval en Pays méditerranéen, Paris: CNRS, 1980, p. 409; MAZZI, Maria Serena; RAVEGGI, Sergio - Gli uomini e le cose nelle campagne fiorentine del Quattrocento. Florença: Olschki, 1983, p. 227; BERTHE, Maurice Famines et épidemies dans les campagnes navarraises à la fin du Moyen Âge. Vol. II. Paris: SFIED, 1984, p. 533.
} 
Para maior vantagem ainda o porco era um animal muito fácil de criar, nada selectivo no que se refere à procura de alimento, servindo-lhe todos os desperdícios, mesmo aqueles que os outros animais rejeitavam, deambulando livremente pelos campos e pelas ruas dos aglomerados populacionais, a comer tudo quanto de comestível encontravam. Bastava apenas cuidar que eles não entrassem nas terras cultivadas, nomeadamente naquelas onde vicejavam os produtos mais mimosos. E se é certo, como já tantos investigadores tiveram oportunidade de comprovar, que até mesmo os citadinos procuravam criar junto de si alguns exemplares, tanto quanto as posturas municipais lhes permitiam ${ }^{21}$, então no campo, onde não existiam entraves legais, vivendo em quase liberdade pelos matos, charnecas e restolhos da aldeia, não causavam grandes gastos nem trabalhos. Todos os aldeãos procuravam criar alguns suínos com vista à matança invernal e a outras utilizações, nomeadamente a venda a um carniceiro de passagem. E como, mercê dos processos de criação na altura praticados, bem mais morosos do que os actualmente conhecidos e a exigirem três ou quatro anos para a obtenção de um animal adulto ${ }^{22}$, convinha que cada família possuísse várias reses, de modo a poder, em cada ano, sacrificar ao menos uma delas ${ }^{23}$. Eram sempre muitos os porcos que por toda a parte vagueavam e era mercê dessa mesma circunstância - a

\footnotetext{
${ }^{21}$ A abonação de bibliografia comprovativa, num caso como este em que os exemplos são de tal modo numerosos, é talvez redundante. Limitar-me-ei, por isso, a lembrar algumas posturas de cidades e vilas portuguesas, posturas essas tendentes a disciplinar a criação de porcos dentro da cidade e a afastá-los dos locais onde eles podiam causar maiores transtornos: POSTURAS DO CONCELHO de Lisboa (século $X I V)$. Apresentação de Francisco José Veloso, leitura paleográfica, nótula e vocabulário de José Pedro Machado. Lisboa: Sociedade de Língua Portuguesa, 1974, pp. 50-51; LIVRO DAS POSTURAS ANTIGAS. Leitura paleográfica e transcrição de Maria Teresa Campos Rodrigues. Lisboa: Câmara Municipal de Lisboa, 1974, pp. 67, 73, 250; VEREAÇÕES DA CÂMARA MUNICIPAL do Funchal, vol. II, Primeira metade do século XVI. Ed. por José Pereira da Costa. Funchal: Secretaria Regional do Turismo e Cultura, 1998, pp. 130-131; ACTAS DE VEREAÇÃO de Loulé. Século XV. supl. de Al'-Ulyā, n. ${ }^{\circ} 10$. Loulé: Arquivo Histórico Municipal de Loulé, 2004, pp. 130-131; LIVRO DA VEREAÇÃO de Alcochete e Aldeia Galega (1421-1422). Introdução, transcrição e notas de José Manuel Vargas. Alcochete: Câmara Municipal de Alcochete, 2005, pp. 162, 182, 185.

22 Vários autores se têm referido ao assunto. Podem ver-se, entre outros: BARUZZI, Marina; MONTANARI, Massimo - Porci e porcari nel Medioevo. Paesaggio, economia, alimentazione. Bolonha: Museo della Civilita Contadina, 1981, p. 41; BIASOTTI, Mirella; ISETTI, Paola - "L'alimentazione dall' osteologia animali in Liguria". Archeologia medievale 8 (1981), pp. 242-244; BECK, Corinne - "Animal et vie quotidienne en France et en Italie d'après les vestiges ostéologiques (XI ${ }^{\text {ème}}-\mathrm{XV}^{\text {ème }}$ siècles)". in Le monde animal et ses representations au Moyen Âge, (XI ${ }^{e}-X V^{e}$ siècles). Actes du XVème Congrès de la Société des historiens médiévistes de l'enseignement supérieur public, Toulouse, 25-26 mai 1984. Toulouse: Publications de l'Université de Toulouse-Le Mirail, 1985, p. 107; MONTANARI, Massimo "Dal bosco alla stalla. Il maiale nel Medioevo". in Uomini, terre, boschi nell'Occidente medievale. Catania: Cooperativa Universitaria Catanese di Magistero, 1992, p. 175; CLEMENTE RAMOS, Julián La economía campesina en la Corona de Castilla (1000-1300). Barcelona: Crítica, p. 140.

${ }^{23}$ Julián CLEMENTE RAMOS (La economía campesina..., p. 140) é de opinião que para a família camponesa poder dispor, em cada ano, de um ou por vezes de dois animais para a matança precisava, não só de possuir várias reses, mas também de uma porca para criação.
} 
possibilidade de vaguearem por toda a parte - que permitia a criação de efectivos bem numerosos.

Mas o lugar de eleição para a pastagem dos suínos era a mata ${ }^{24}$, onde eles podiam diversificar a sua alimentação, indo das folhas, das bagas, das raízes, dos fungos, aos rebentos e, sobretudo aos frutos de Outono, bolotas, landes, castanhas. Aliás, procuravase sempre alimentá-los desse modo durante alguns meses do ano, já que era com aqueles e outros frutos do bosque que a carne suína devia resultar bastante mais saborosa, porque próxima da da espécie selvagem, o javali ${ }^{25}$. Por tudo isto, os montes medievais sempre deram acolhida a numerosas piaras de porcos e se, durante a época aqui tratada, eles já não faziam aí tão longas estadias nem seriam tão quantiosos como em períodos anteriores em que a sua presença era aí tão significativa que a floresta se media pelo número de porcos que podia alimentar ${ }^{26}$, eles continuavam a ser seus frequentadores tão assíduos quanto possível e em quantitativos bastante elevados ${ }^{27}$.

Todos quantos tinham essa oportunidade aproveitavam-na para levar os seus porcos à mata, onde permaneciam, em regra, durante todo o período da montanheira, isto é,

${ }^{24}$ O que já muitos investigadores reconheceram e, entre eles: GRAND, Roger; DELATOUCHE, Raymond - L'agriculture au Moyen Âge. De la fin de l'Empire romain au XVI siècle. Vol. II de SAVOY, Émile (dir.) - L'agriculture à travers les âges. Paris: Ed. de Boccard, 1950, p. 509; DUBY, Georges - L'économie rurale et la vie des campagnes dans l'Occident médiéval (France, Angleterre, Empire, IX $X^{e}-X V^{e}$ siècles). Essai de synthèse et perspectives de recherche. Vol. I. Paris: Aubier, 1962, p. 241; GONÇALVES, Iria - O património do mosteiro de Alcobaça..., p. 267; CONDE, Manuel Sílvio Alves - Uma paisagem humanizada. O Médio Tejo nos finais da Idade Média. Vol. I. Cascais: Patrimonia, 2000, p. 262; PÉREZ-EMBID, Javier - "El Císter hispano y la ganadería". in ARÍZAGA BOLUMBURU, Beatriz et alii (ed.) - Mundos medievales: espacios, sociedades y poder. Homenaje al Profesor José Ángel García de Cortázar y Ruiz de Aguirre.T. II. Santander: PUbliCan - Ediciones de la Universidad de Cantabria, 2012, p. 1774; VICENTE, Maria da Graça - Povoamento e propriedade entre o Zêzere e o Tejo (séc. XII-XIV). Lisboa: Ed. Colibri, 2015, p. 258.

25 Assim o considerava Rui FERNANDES (Descrição do terreno ao redor de Lamego duas léguas [1531-1532]. Ed. crítica de Amândio Morais Barros. Lamego: Beira Douro, 2001, p. 60), opinião que continua válida.

${ }^{26} \mathrm{O}$ que desde há muito tem sido repetido: $\mathrm{BLOCH}$, Marc - Les caractères originaux de l'histoire rurale française. $2^{\mathrm{a}}$ ed., vol. I. Paris: Armand Colin,1953, pp. 30-32; GRAND, Roger e DELATOUCHE, Raymond - L'agriculture au Moyen Âge..., pp. 411-414; SCLAFERT, Thérèse - Cultures en Haute Provence. Deboissement et pâturage au Moyen Âge. Paris: S.E.V.P.E.N., 1959, pp. 61-67; DEVÈZE, Michel - La vie de la forêt française au XVI siècle. Vol. I. Paris: S.E.V.P.E.N., 1961, pp. 81-105; HIGOUNET, Charles - "Les forêts de l'Europe Occidentale du V $\mathrm{V}^{\mathrm{e}}$ au XI $\mathrm{XI}^{\mathrm{e}}$ siècle". in Paysages et villages neufs du Moyen Âge. Bordéus: Fédération Historique du Sud Ouest, 1975, p. 41; BARUZZI, Marina e MONTANARI, Massimo - Porci e porcari nel Medioevo..., p. 29; GALETTI, Paola - "Bosco e spazi incolti nel territorio piacentino durante l'Alto Medioevo". in ANDREOLLI, Bruno; MONTANARI, Massimo (eds.) - Il bosco nel Medioevo. Bolonha: Casa Editrice Clube, 1990, p. 203.

${ }^{27}$ GONÇALVES, Iria - O património do mosteiro de Alcobaça..., pp. 262, 266; CONDE, Manuel Sílvio Alves - Uma paisagem humanizada..., vol. I, p. 262. 
durante o tempo em que a bolota e outros frutos do inculto, chegada a época de amadurecimento, constituíam para eles farta e excelente alimentação. Durante esse tempo, aí viviam em regime de liberdade, guardados por porcariços e recolhidos, durante a noite, em redutos construídos nas clareiras ${ }^{28}$, que os predadores não faltariam, atraídos pela sua presença ${ }^{29}$.

Durante esse tempo - finais do Outono, princípios de Inverno -, os porcos ficavam parcialmente cevados, podendo engordar metade do peso que tinham aquando da sua entrada na mata ${ }^{30}$. Era um lucro a não desprezar. Tratando-se de animais para venda, o aproveitamento da montanheira representava já uma grande vantagem para a negociação dos preços; tratando-se daquele que se havia escolhido para a matança do ano ou, no caso de muitas famílias citadinas, daquele que havia sido comprado para o mesmo efeito $^{31}$, esse acabaria depois de ser cevado junto de casa, com toda a espécie de restos possíveis de carrear ${ }^{32}$. Podia até acontecer, durante a época da montanheira, que, em algum lugar, enquanto os suínos andassem comendo a bolota, nenhum outro gado pudesse entrar na floresta ${ }^{33}$.

${ }^{28}$ GRAND, Roger e DELATOUCHE, Raymond - L'agriculture au Moyen Âge..., p. 511; ARGENTE DEL CASTILLO OCAÑA, Carmen - La ganadería medieval andaluza..., vol. I, pp. 122, 124; CARMONA RUIZ, María Antonia - La ganadería en el reino de Sevilla..., p. 290.

${ }^{29}$ Não faltavam em todos os espaços boscosos os predadores de grande e médio porte, sobretudo os lobos, que infestavam as florestas. É certo que o lobo ibérico (descrito por CORREIA, Clara Pinto - Portugal animal. Fotografias de António José Cidadão. Lisboa: Relógio D’Água, 2000, pp. 167-168) podia ser mais pequeno do que a fera apresentada por Robert DELORT (Les animaux ont une histoire. Paris: Seuil, 1984, p. 317), mas o facto de em regra caçar em grupo, um grupo bem organizado e estruturado à volta de um casal dominante acompanhado por cinco ou seis adultos, entre os quais se estabelece uma hierarquia que não admite quebras (DELORT, Robert - Les animaux..., p. 318) torna-o uma fera digna de respeito.

${ }^{30}$ CABRERA MUÑOZ, Emilio - "El bosque, el monte...", p. 259.

${ }^{31}$ Também os citadinos podiam ter varas de porcos que, nesse caso, dariam a criar, mas eram sobretudo os aldeãos que, melhor posicionados para o efeito, possuíam as maiores criações que, depois, ofereciam para venda.

${ }^{32}$ Eram esses, sobretudo, os porcos que nas cidades deambulavam pelas ruas. Eram esses que, em Évora, se dizia serem "porcos e porcas de çeva" "LIVRO DAS POSTURAS ANTIGAS de Évora". [Transcrição de] Ana Sesifredo, Fátima Farrica e Miguel Meira. in Posturas municipais portuguesas (séculos XIVXVIII). Ponta Delgada: Centro de Estudos Gaspar Frutuoso, 2012, p. 42); eram esses que, em Loulé, se levavam a pastar até nas eiras, após malhas e debulhas feitas, pois se "leixavam em ellas muitos cachos e espigas" que, naturalmente, eles aproveitavam (Actas de vereação de Loulé. Século XV, p. 44); eram esses que o mosteiro de Alcobaça entregava a alguns dos seus foreiros, às vezes, moleiros, para lhos restituírem já acabados de cevar (Arquivos Nacionais / Torre do Tombo, Ordem de Cister, Mosteiro de Santa Maria de Alcobaça, $2^{a}$ incorporação, mç. 86, doc. s/n $\mathrm{n}^{\circ}$; Ordem de Cister, Mosteiro de Santa Maria de Alcobaça, lv. 15, fol. 14v. ${ }^{\circ}, 14 v^{\circ}{ }^{\circ}-15$; doravante TT, $O$. Cist., Alc.).

${ }^{33}$ ARGENTE DEL CASTILLO OCAÑA, Carmen - La ganadería medieval andaluza..., vol. I, p. 123. 


\section{III - As matas, o porco e o montado nas terras de Alcobaça}

\section{III.1 - As matas}

Sendo a mata formação imprescindível a uma Idade Média que de tantas maneiras a utilizava, ela tinha de encontrar-se, mais ou menos dispersa e desgastada, mais ou menos compacta e bem cuidada, mas ajudando a compor todas as paisagens. E assim obviamente, nas terras senhoriadas pelo mosteiro de Alcobaça, onde toda a extensão dos coutos se encontrava ponteada por grandes e pequenas matas, a servirem todos os moradores $^{34}$.

Na sua grande parte - a excepção encontra-se no arvoredo que dava apoio às povoações de Pederneira, Pataias e Paredes, cuja dominância pertencia ao pinheiro ${ }^{35}$-, elas representavam os restos do que fora o revestimento florestal primitivo daquele espaço em épocas muito anteriores a estas que aqui estão a ser abordadas e eram compostas essencialmente por plantas espontâneas e até autóctones, com as dominâncias centradas, alternada ou conjuntamente, no sobreiro e no carvalho, este, em parte o carvalho negral $^{36}$, mas sobretudo o cerquinho ${ }^{37}$, como, aliás, ainda nos nossos dias ${ }^{38}$. Para lá de

\footnotetext{
${ }^{34}$ Veja-se uma tentativa de localização dessas matas em GONÇALVES, Iria - O património do mosteiro de Alcobaça..., p. 103. Pode ver-se também um levantamento da cobertura arbórea da região na Idade Média feita por BARBOSA, Pedro Gomes - Povoamento e estrutura agrária da Estremadura Central. Séc. XII a 1325. Lisboa: INIC, 1992, pp. 25-34.

35 GONÇALVES, Iria - O património do mosteiro de Alcobaça..., p. 103. Veja-se também GONÇALVES, Iria - "Traços da paisagem rural nas terras de Alcobaça (séculos XIV-XV)". in Tarouca e Cister. Espaço, espírito e poder. Actas, Setembro 2002. Tarouca: Câmara Municipal de Tarouca, 2004, pp. 387-388, ou CASTRO, Armando de - "Pinhal de Leiria". in SERRÃo, Joel (dir.) - Dicionário de História de Portugal. Vol. III. Lisboa: Iniciativas Editoriais, 1968, pp. 385-386.

${ }^{36}$ Segundo João do Amaral FRANCO ("Carvalho". in Verbo. Enciclopédia luso-brasileira de cultura. Vol. 4. Lisboa: Verbo, [1992], col. 1249), o carvalho negral, espontâneo no centro da Península, é a árvore mais característica das serras do Centro e Oeste.

${ }^{37} \mathrm{O}$ carvalho cerquinho, ou português é a Quercus que melhor se adapta a estas terras (RIBEIRO, Orlando - Portugal, o Mediterrâneo e o Atlântico. Esboço de relações geográficas. $2^{\mathrm{a}}$ ed. Lisboa: Sá da Costa, 1963, p. 55) e encontra-se aqui bem documentado durante os séculos medievais (NATIVIDADE, Joaquim Vieira; MACEDO, Jorge Borges - "As instituições e as técnicas na história regional". in SILVA, Carlos da, ALARCÃO, Alberto; CARDOSO, António Poppe Lopes - A região a Oeste da Serra dos Candeeiros. Estudo económico-agrícola dos concelhos de Alcobaça, Nazaré, Caldas da Rainha, Óbidos e Peniche. Lisboa: Fundação Calouste Gulbenkian - Centro de Estudos de Agronomia Agrária, 1961, p. 89; GONÇALVES, Iria - O património do mosteiro de Alcobaça..., p. 101).

${ }^{38}$ NATIVIDADE, Joaquim Vieira - A região de Alcobaça. Algumas notas para o estudo da sua agricultura, população e vida rural. Obras várias. Vol. I. Alcobaça: s.n., s.d., pp. 116-117; SILVA, Carlos da, ALARCÃO, Alberto; CARDOSO, António Poppe Lopes - A região a Oeste da Serra dos Candeeiros. Estudo económico-agrícola dos concelhos de Alcobaça, Nazaré, Caldas da Rainha, Óbidos e Peniche. Lisboa: Fundação Calouste Gulbenkian - Centro de Estudos de Economia Agrária, 1961, pp. 5460; FERNANDES, João Luís Jesus - O homem, o espaço e o tempo no Maciço Calcário Estremenho. $O$
} 
alguns pequenos soutos à volta da abadia, formados, em preponderância, pelo castanheiro $^{39}$. Mas como todas as florestas climácicas, que estas eram, apresentavam-se compostas por grande heterogeneidade florística, que aqui se mostrava particularmente rica, a reflectir a interpenetração de influências climáticas que no nosso País se verificam, com as respectivas consequências no comportamento da flora. Aspecto este que, segundo Orlando Ribeiro, constitui a característica fundamental da vegetação portuguesa. Com efeito, em Portugal - e isso torna-se muito significativo na região agora em estudo - encontram-se, para muitas plantas, os seus limites meridionais ou setentrionais, conforme elas têm adaptação ao clima da Europa Média ou do Mediterrâneo $^{40}$, mas coexistindo todas elas. E se a mais vincada dessas influências nas terras de Alcobaça é a do clima mediterrânico, os solos calcários aqui encontrados ${ }^{41}$, por serem quentes e secos favorecem o desenvolvimento dessas plantas ${ }^{42}$, pelo que acolhem em boas condições azinheiras, carrascos e outras árvores e arbustos muito enriquecedores destas matas ${ }^{43}$ e em especial na vertente que aqui mais interessa: na generosa dádiva de frutos de Outono. Assim sendo não apenas pelas dominâncias ${ }^{44}$ mas também pelas outras plantas que as acompanhavam, em todas as matas haveria bom alimento para os cerdos da terra e ainda outros, de fora, que aí vinham. Assim o ano se mostrasse de feição.

\section{III.2 - Os direitos de uso - o montado}

Como a generalidade dos senhores medievais dentro das terras da sua jurisdição, os monges de Alcobaça reservavam para si próprios, em exploração directa, a totalidade

olhar de um geógrafo. Lisboa / Coimbra: Ed. Colibri / Faculdade de Letras da Universidade de Coimbra, 2000, p. 120.

${ }^{39}$ De novo remeto para GONÇALVES, Iria - O património do mosteiro de Alcobaça..., p. 103.

${ }^{40}$ RIBEIRO, Orlando - Portugal, o Mediterrâneo e o Atlântico..., p. 53; RIBEIRO, Orlando - "O manto vegetal”. in RIBEIRO, Orlando; LAUTENSACH, Hermann - Geografia de Portugal. Org., comentários e actualização por Suzanne DAVEAU. Vol. II, O ritmo climático e a paisagem. Lisboa: Ed. João Sá da Costa, 1988, p. 577.

${ }^{41}$ Sobre a geologia destes terrenos veja-se FERNANDES, João Luís Jesus - O homem, o espaço e o tempo...

${ }^{42}$ LAUTENSACH, Hermann - "A cobertura vegetal”. in RIBEIRO, Orlando; LAUTENSACH, Hermann - Geografia de Portugal. Org., comentários e actualização por Suzanne DAVEAU. Vol. II, O ritmo climático e a paisagem. Lisboa: Ed. João Sá da Costa, 1988, p. 547.

43 Sobre as plantas que acompanham estas formações boscosas pode ver-se, por exemplo: CABRAL, Francisco Caldeira; TELLES, Gonçalo Ribeiro - A árvore em Portugal. Lisboa: Assírio \& Alvim, 1999, p. 42.

44 Para a Idade Média a documentação de Alcobaça é muito parca em informações sobre a cobertura florestal. A primeira descrição que dela subsistiu reporta-se já às primeiras décadas de Quinhentos e encontra-se em TT, O. Cist., Alc., lv. 212, fol. 62v-65. 
dos incultos, de uma maneira especial, porque os mais importantes, as águas e as matas. Mas como o uso de umas e outras era imprescindível para todos, os seus colonos tinham o direito de usufruir das potencialidades destes bens. Era mister que para ambas as partes se apresentasse como um dado adquirido que o uso dos incultos era acessível a todos. Mediante, como não podia deixar de ser, determinadas regras que se foram estabelecendo a pouco e pouco, de modo a impedir uma usufruição indisciplinada e abusiva e assim a completa deterioração desses mesmos recursos. Eram os direitos de uso, de que os camponeses não podiam prescindir.

Como em todo o lado, assim também nas terras de Alcobaça, onde se foi firmando um direito regulamentador da utilização, sobretudo das matas que, embora haja sobejas provas documentais da sua aplicação durante os séculos XIV e $\mathrm{XV}^{45}$, só conheceu fixação bem estabelecida e de certo modo uniforme para toda a região dos coutos no princípio do século XVI e aí apenas no que se refere aos aspectos mais importantes ${ }^{46}$. As normas então estabelecidas baseavam-se em sentenças decorrentes de pleitos entre o mosteiro e algumas das suas vilas e posteriormente aprovadas por D. João I e por D. Duarte $^{47}$, as quais pouco se afastavam do que os monges afirmavam ser a prática então vigente. Prova da sua aplicação em épocas mais recuadas e em moldes sensivelmente iguais aos da redacção definitiva.

No entanto, nos forais primitivos concedidos pelos abades às vilas dos coutos e no que se refere à pastagem dos gados dos camponeses nas matas senhoriais e de uma maneira geral em todos os incultos, nada de restritivo se encontra fixado, pelo que nesses tempos ela seria livremente praticada. Para mais, neles se explicitava que os gados do mosteiro e os dos camponeses deviam beber as águas e pascer as ervas em conjunto, ou que montes, fontes e pascigos seriam comuns a todos eles, ou ainda, embora aqui olhando de uma outra perspectiva, que os danos causados pelos animais deviam ser reparados

\footnotetext{
${ }^{45}$ Podem encontrar-se já bem firmadas em: TT, O. Cist., Alc., $2^{a}$ inc., mç. 2, n. $^{\circ} 62 ; 1^{a}$ inc., mç. 35, n. $^{\circ} 28$; lv. 3, fol. 55-55v. ${ }^{\circ}$; lv. 12, fol. 2v. ${ }^{\circ}-3 v^{\circ}$, mas sobretudo lv. 15, fol. 34, 48-48v, 67-67v, 89, 92, 94-94v, $100-100 \mathrm{v}, 109,118,121 \mathrm{v}-122$.

${ }^{46}$ FORAIS MANUELINOS do reino de Portugal e do Algarve conforme o exemplar do Arquivo Nacional da Torre do Tombo de Lisboa - Estremadura. Ed. por Luiz Fernando de Carvalho Dias. Lisboa: L. F. C. Dias, 1962, pp. 149-150.

47 FORAIS MANUELINOS, p. 149. Adiante serão referidas algumas dessas sentenças, até porque elas respeitam sobretudo ao direito de montado.
}

Medievalista online № 22 | Julho - Dezembro 2017 ( I IEM - Instituto de Estudos Medievais 13 www2.fcsh.unl.pt/iem/medievalista 
"de vizinho a vizinho" 48 . Isto é, frequentariam as matas sem pagar qualquer direito ao senhor ${ }^{49}$.

Não me foi possível saber de que modo, durante esses primeiros tempos de fixação dos Cistercienses no território, a permanência dos suínos nas áreas boscosas se processava, e se conhecia alguma regulamentação, mas é de crer que pelo menos durante a Primavera, quando os brotos das árvores e as plantas jovens são mais vulneráveis, eles fossem daí afastados. Assim também não há notícias seguras de quando começaram a pagar montado. Um documento de 1380 respeitante a Aljubarrota diz-nos que desde o começo da povoação até 1357, pouco mais ou menos, o concelho esteve na posse de uma mata no termo para pascigo dos seus gados e para outras utilizações várias e que só a partir daí os abades começaram a colocar entraves ao livre usufruto da mata ${ }^{50}$. Certo é, porém, que daí em diante começam a surgir as informações mais significativas nesta matéria, mas já em contexto de oposição aberta entre o mosteiro e as vilas ${ }^{51}$. Nesta altura o montante do direito e a época de pastagem estavam já perfeitamente fixados, sem que, porém, nos fossem dados a conhecer.

Se existia em Alcobaça mais do que uma época de pastagem na mata para os suínos, como acontecia em outras regiões da Europa ${ }^{52}$, não foi possível saber. Fixar com rigor o início dessa única época documentada também não foi possível averiguar. Apenas, isso sim, que, como geralmente acontecia, se localizava por alturas de finais de Setembro ${ }^{53}$,

\footnotetext{
${ }^{48}$ Veja-se, por exemplo: TT, $O$. Cist., Alc., $2^{a}$ inc., mç. $1, \mathrm{n}^{\circ} 1$. É este um pequeno caderno onde foram recolhidos vários dos primitivos forais e a sua leitura ilustra bem diversos aspectos das relações entre o mosteiro e os seus colonos durante os primeiros tempos da sua estadia em Alcobaça. Pode ver-se também BARBOSA, Pedro Gomes - Povoamento e estrutura agrária da Estremadura Central..., p. 144.

${ }^{49}$ Também Maria Helena da Cruz COELHO, (O Baixo Mondego nos finais da Idade Média (Estudo de história rural). Vol. I. Coimbra: Imprensa Nacional - Casa da Moeda, 1989, pp. 239-240) e Javier PÉREZ-EMBID, (“El Císter hispano y la ganadería...”, p. 1775) encontraram a mesma situação.

${ }^{50}$ TT, O. Cist., Alc., $2^{a}$ inc., mç. 62 , no ${ }^{\circ}$; lv. 12, fol. 36v-38v.

${ }^{51}$ TT, O. Cist., Alc., $2^{a}$ inc., mç. $2, \mathrm{n}^{\circ} 62 ;$ mç. $62, \mathrm{n}^{\circ} 6$; mç. 64, $\mathrm{n}^{\circ} 33 ; 1^{a}$ inc., mç. $35, \mathrm{n}^{\mathrm{o}} 28$; lv. 3, fol. $55-$ $55 \mathrm{v}$; 1v. 12 , fl. $2 \mathrm{v}-3 \mathrm{v}, 3 \mathrm{v}-4 \mathrm{v}, 36 \mathrm{v}-38 \mathrm{v}$.

${ }_{52}$ As épocas de pastagem nas matas podiam variar muito ao longo do tempo e do espaço e ser apenas uma ou mais do que uma. Podem ver-se, entre outros trabalhos: GRAND, Roger e DELATOUCHE, Raymond - L'agriculture au Moyen Âge..., pp. 509-510; SANTIARD, Marie-Thérèse - "La glandée dans les forêts ducales au XIV ${ }^{e}$ siècle d'après les comptes de gruerie". in Annales de Bourgogne XLVI (Out.-Dez. 1974), pp. 194-197; CABRERA MUÑOZ, Emilio - "El bosque, el monte y su aprovechamiento...”, p. 258.

${ }^{53}$ ARGENTE DEL CASTILLO OCAÑA, Carmen - La ganadería medieval andaluza ..., vol. I, p. 123; CABRERA MUÑOZ, Emilio - "El bosque, el monte y su aprovechamiento...", p. 258; CARMONA RUIZ, María Antonia - La ganadería en el reino de Sevilla..., p. 110; CLEMENTE RAMOS, Julián -
} 
com o amadurecimento da bolota e de outros frutos do inculto, para terminar em princípios de Janeiro. Para os gados de fora dos coutos o período de pastagem era, no entanto, bastante mais curto, pois terminaria pelo S. Martinho, dia 11 de Novembro ${ }^{54}$.

Também não foi possível saber se eram colocadas algumas restrições ao varejamento das landes para provocar a sua queda e proporcionar maior abundância e maior facilidade à alimentação dos animais $^{55}$ ou se ele era livremente praticado após a maturação dos frutos ${ }^{56}$. Sabe-se, isso sim, que em tempos passados, colher lande e por certo levá-la para fora da mata, de modo a poder ser consumida após o termo da época de pastagem e talvez até como reserva dos anos de safra para os de contra-safra ${ }^{57}$ era prática corrente.

Sabe-se também que, chegada a altura de introduzir os cerdos na mata - "ao tenpo que ouuerem de leuar seus porcos aas dictas matas" 58 -, os respectivos donos deviam mostrá-los aos mateiros ${ }^{59}$, ocasião em que seriam contados e o seu número registado no chamado "livro do montado" 60 , livro renovado todos os anos, quando não se faziam as

"La ganadería porcina de Jarandilla de la Vera a mediados del siglo XV". in FONSECA, Luís Adão; AMARAL, Luís Carlos; SANTOS, Maria Fernanda Ferreira (ed.) - Os reinos ibéricos na Idade Média. Livro de homenagem ao Professor Doutor Humberto Carlos Baquero Moreno. Vol. II. Porto: Livraria Civilização Editora, 2003, p. 744; MARTÍN GUTIÉRREZ, Emilio - Paisajes, ganadería y medio ambiente en las comarcas gaditanas..., p. 49.

${ }^{54} \mathrm{TT}$, O. Cist., Alc., $1^{a}$ inc., mç. 32, $\mathrm{n}^{\circ} 22$.

${ }^{55}$ Em Abrantes, como exemplo, o varejamento era proibido, por certo aos homens de fora-parte, embora cada um nos seus lavradios pudesse fazer como quisesse: "O LIVRO DE POSTURAS da vila de Abrantes de 1515". Ed. com nota explicativa de J. Candeias Silva. in Abrantes - Cadernos para a história do município 1 (1982), pp. 82, 92.

${ }^{56}$ Sabe-se, por exemplo, que o mosteiro de Moreruela, que tinha possessões em Trás-os-Montes, gozava do privilégio de os seus gados poderem pastar em todo o lado e de os seus pastores obterem tudo o que necessitassem, incluindo varas compridas para varejar a lande (ALFONSO ANTÓN, Isabel - La colonización cisterciense en la meseta del Duero. El dominio de Moreruela (siglos XII-XIV). Zamora: Instituto de Estudios Zamoranos Florián de Ocampo - Diputación Provincial de Zamora, 1986, p. 173). Aliás, essa operação pode ver-se representada em diversos livros de Horas, a ilustrar os meses em que ela era praticada.

57 Joaquim Pedro Fragoso de SEQUEIRA diz-nos que bolotas e landes se podem conservar secas de uns anos para os outros e que os porcos as comem assim tão bem como verdes, embora seja melhor amolecêlas em água, antes de lhas dar ("Memória sobre as azinheiras, sovereiras e carvalhos da província do Alentejo, onde se trata da sua cultura, e usos, e dos melhoramentos, que no estado actual podem ter". in Memórias económicas da Academia Real das Ciências de Lisboa, para o adiantamento da cultura, das artes e da indústria em Portugal e suas conquistas (1789-1815). t. II, dirig. por José Luís CARDOSO. Lisboa: Banco de Portugal, 1991, p. 270).

${ }^{58}$ TT, O. Cist., Alc., lv. 15, fol. 109v.

${ }^{59}$ TT, O. Cist., Alc., $2^{a}$ inc., mç. $2, \mathrm{n}^{\circ} 22 ; 1^{a}$ inc., mç. $35, \mathrm{n}^{\circ} 28 ; 1 \mathrm{lv} .3$, fol. $55-55 \mathrm{v} ; 1 \mathrm{v} .12$, fol. $2 \mathrm{v}-3 \mathrm{v} ; 1 \mathrm{v} .15$, fol. $70,74 \mathrm{v}, 90,100,109 \mathrm{v}, 121 \mathrm{v}-122$.

${ }^{60}$ TT, O. Cist., Alc., $2^{a}$ inc., mç. 70 , doc. $\mathrm{s} / \mathrm{n}^{\circ}$. 
alterações necessárias no que servira durante o ano anterior, prática que era comum. Infelizmente, tanto quanto sei, nenhum desses livros medievais chegou até nós. Por eles, terminado o período da montanheira, era feita a cobrança do direito na presença do abade ou de um seu representante, sendo os dias e o lugar escolhidos para o efeito ${ }^{61}$ anunciados em cada vila mediante pregão público ${ }^{62}$. Os residentes em Alvorninha, porque a vila mais distanciada do centro nevrálgico do território, veriam os seus porcos tributados num "lugar comarcão"63.

O direito era cobrado na base da vintena de animais, de entre a qual o dono separava um deles, que ficava isento da escolha do senhor e essa exercer-se-ia sobre os restantes dezanove. Cada vintena, porém, devia ser constituída por animais de tamanho mais ou menos homogéneo. No foral manuelino ficaria estabelecido que o direito do mosteiro era "dos porcos grandes levar porco grande $\mathrm{E}$ dos pequenos pequeno $\mathrm{E}$ dos meaãos per esse Respeito" ${ }^{64}$. Ficavam excluídos da contagem os leitões ainda em período de amamentação. Além disso, pelo menos em algumas povoações - Évora, Turquel, Santa Catarina, Alvorninha -, para além daquele porco pago em função da vintena, o senhor tinha direito a receber mais um, chamado "de assadura" 65 , por cada grupo de cinquenta e, nesse caso, independentemente de o grupo ser, ou não, homogéneo. Mais ainda, o animal escolhido estava determinado que fosse um dos melhores da vara ${ }^{66}$. Podia ainda acrescentar-se que "asi quantos cinquenta porcos tantos porcos d assadura" 67.

Que estes eram os quantitativos de pagamento do montado nas terras alcobacenses, pelo menos a partir de finais do século XIV, parece não ser passível de dúvidas, dada a soma de documentação que nos traz os mesmos informes e a sua fixação no foral

${ }^{61} \mathrm{TT}$, O. Cist., Alc., lv. 15, fol. $74 \mathrm{v}$.

${ }^{62} \mathrm{TT}$, O. Cist., Alc., $2^{a}$ inc., mç. $29, \mathrm{n}^{\circ} 708,712,715,717$; lv. 12, fol. $139 \mathrm{v}-140 \mathrm{v}$.

${ }^{63}$ TT, O. Cist., Alc., lv. 15, fol. 100.

${ }^{64}$ FORAIS MANUELINOS do reino de Portugal e do Algarve, Estremadura, p. 149.

${ }^{65}$ Julius KLEIN (La Mesta..., p. 441), define a "assadura" como um pequeno imposto remontando ao século $\mathrm{X}$ e que em princípio se cobrava sob a forma da assadura da ovelha e de outro gado, o que pressupunha o consumo do animal na altura da cobrança. Evoluiria, posteriormente, para uma quantia em dinheiro. Outros investigadores repetiram estes dizeres sem nada mais acrescentarem, como, entre outros, ARGENTE DEL CASTILLO OCAÑA, Carmen - La ganadería medieval andaluza..., vol. II, pp. 645646; GUADALAJARA SOLERA, Simón - Lo pastoril en la cultura extremeña. Cáceres: Institución Cultural El Brocense, 1984, p. 43. A documentação que tenho vindo a compulsar também nada permite adiantar.

${ }^{66}$ TT, O. Cist., Alc., lv. 15, fol. 100, 109v, 117v, 121v-122.

${ }^{67}$ TT, O. Cist., Alc., lv. 15, fol. 109v. 
quinhentista. O que nos coloca perante varas de suínos muito numerosas, aparentemente a poderem ser detidas por muitas famílias camponesas da terra.

É certo que há aqui lugar para piaras de todos os tamanhos, na medida em que as fontes que tenho vindo a citar acrescentam que os animais sobejantes da vintena seriam tributados a dinheiro, uma determinada quantia por cabeça ${ }^{68}$, a qual, nos fins do século XIV estava fixada em cinco soldos ${ }^{69}$ e mais tarde, no segundo quartel de Quatrocentos era de três reais em determinadas localidades ${ }^{70}$, de dois em outras ${ }^{71}$ e ainda de meio real em algumas ${ }^{72}$. O que contempla também piaras inferiores a vinte animais. Porém, se a base da tributação era a vintena, para mais uma vintena que se multiplicava por três - a dos grandes, a dos pequenos e a dos médios, como atrás ficou dito - penso ser obrigatório que essa base fosse realista e pudesse ser aplicada com alguma generalidade.

Que a maior parte dos camponeses da terra, como os de outros lugares, possuía suínos nas suas várias fases de crescimento, era quase certo. Se eles queriam abastecer a despensa de carne porcina para todo o ano e queriam também promover a reprodução dos seus efectivos, precisavam ter porcos adultos; se pensavam nos anos seguintes, querendo dar continuidade à piara, necessitavam de juvenis $^{73}$ e recentais. Independentemente daquelas reses que quisessem colocar no mercado, que essas podiam ser oferecidas para venda em qualquer altura das suas vidas. Deste modo teriam de ser sempre piaras heterogéneas aquelas que as gentes dos coutos, como as de fora deles que aí se dirigiam, introduziam nas matas do mosteiro.

É certo que na falta dos livros medievais de registo do montado, não existem quaisquer outros elementos susceptíveis de nos mostrar de forma credível os valores atingidos por

\footnotetext{
${ }^{68}$ TT, O. Cist., Alc., lv. 15, fol. 74v, 90, 100, 109v, 117v, 121v-122.

${ }^{69}$ TT, O. Cist., Alc., $2^{a}$ inc., mç. 2, $\mathrm{n}^{\mathrm{o}} 22$; mç. 64, $\mathrm{n}^{\mathrm{o}} 33 ; 1^{a}$ inc., mç. 35, $\mathrm{n}^{\mathrm{o}} 28$; lv. 3, fol. 55-55v; 1v. 12, fol. $2 \mathrm{v}-3 \mathrm{v}, 3 \mathrm{v}-4 \mathrm{v}$.

${ }^{70}$ TT, O. Cist., Alc., lv. 15, fol. 90, 100, 109v.

${ }^{71}$ TT, O. Cist., Alc., $2^{a}$ inc., mç. 26, n 666; lv. 3, fol. 21v-22, 22-23; lv. 15, fol. 74v.

72 TT, O. Cist., Alc., lv. 15, fol. $117 \mathrm{v}, 121 \mathrm{v}-122$.

${ }^{73}$ Eram sobretudo animais juvenis - marrãs - que o mosteiro pedia como foragem a vários dos seus foreiros. Podem ver-se, como alguns exemplos entre muitos outros: TT, O. Cist., Alc., $2^{a}$ inc., mç. $38, \mathrm{n}^{\mathrm{o}}$ 923; mç. 46, no 1198; mç. 48, no 1308; mç. 49, no 1329; mç. 86, docs. s/no; $1^{a}$ inc., mç. 39, $\mathrm{n}^{\text {o }} 13$; mç. 42, $\mathrm{n}^{\circ} 4$; lv. 136, fol. 48v-49, 129-130; lv. 183, fol. 22v-23.
} 
aquelas piaras ${ }^{74}$. Dentro das terras e durante a época aqui tratadas só foi possível conhecer um grupo de animais que podia, ou não, ser a totalidade de uma vara. Tratavase de suínos que o seu dono retirava furtivamente da mata para os sonegar ao imposto, no contexto de um contencioso sobre o assunto entre o mosteiro e as suas vilas, não sendo possível saber se antes deles já outro grupo teria saído sem ser notado, ou se alguns mais ainda se encontravam na mata, à espera de sair sem chamar a atenção dos cobradores do montado. O que, todavia, ficou registado, é que o número desses porcos apanhados em acto de sonegação era de vinte e cinco $^{75}$. Ainda assim, muito superior ao que entre nós se tem dito acerca destas matérias ${ }^{76}$.

É verdade que algumas das manadas de porcos podiam ser colectivas e formadas apenas para efeitos da sua entrega a um porcariço que teria o encargo de os guardar durante a época de pastagem nas matas ou talvez durante todo o ano. Mas essa questão nunca se coloca nas fontes medievais alcobacenses e nem sequer se compagina muito bem com alguns dos aspectos que esta matéria coloca, sobretudo quando decorrentes de contextos conflituosos ${ }^{77}$.

Seja como for, o certo é que aqui, nestas terras, os camponeses criavam bastantes porcos e alguns dos residentes, nomeadamente os que tinham uma situação económica capaz de

\footnotetext{
${ }^{74}$ Embora para outras regiões fora de Portugal tenham sido encontradas numerosas informações quantitativas sobre esta matéria, precisamente a partir de registos semelhantes, sem dúvida, aos que se encontrariam nos livros do montado de Alcobaça: GRAND, Roger e DELATOUCHE, Raymond L'agriculture au Moyen Âge..., p. 510; ARGENTE DEL CASTILLO OCAÑA, Carmen - La ganadería medieval andaluza..., vol. I, pp. 171-172; CABRERA MUÑOZ, Emilio - "El bosque, el monte y su aprovechamiento...", p. 258; CLEMENTE RAMOS, Julián - La economía campesina en la Corona de Castilla..., p. 67; CLEMENTE RAMOS, Julián - "La ganadería porcina de Jarandilla de la Vera...", pp. 744-745; SANTIARD, Marie-Thérèse - "La glandée dans les forêts ducales...", pp. 212, 221. A maior parte das piaras reveladas nestes estudos eram pequenas e até muito pequenas, podendo contar apenas algumas, poucas, unidades, mas outras, pertencentes a grandes criadores ou a negociantes de gado, podiam aproximar-se dos trezentos animais, enquanto as dos grandes senhores, essas podiam contar com muitas centenas (sobretudo: GRAND, Roger e DELATOUCHE, Raymond - L'agriculture au Moyen Âge..., p. 508; DUVAL-ARNOULD, Louis - "Les ressources de la forêt royale de Retz et leur place dans l'économie de l'abbaye de Longpont". in L'économie cistercienne. Géographie - Mutations du Moyen Âge aux temps moderns. Publications de la Commission d'Histoire de Flaran, 3. Auch: Comité Départemental du Tourisme de Gers, 1983, p. 195; CLEMENTE RAMOS, Julián - La economía campesina en la Corona de Castilla..., p. 745).

${ }^{75}$ TT, O. Cist., Alc., $2^{a}$ inc., mç. 86, docs. s/no; lv. 12, fol. $142 \mathrm{v}-143 \mathrm{v}$.

${ }^{76}$ Por exemplo: COELHO, Maria Helena da Cruz - O Baixo Mondego nos fins da Idade Média..., vol. I, p. 252; RODRIGUES, Ana Maria Seabra de Almeida - "A produção agro-pecuária". in SERRÃO, Joel; MARQUES, A. H. de Oliveira (dir.) - Nova História de Portugal. Vol. V - Portugal do Renascimento à crise dinástica. Coord. por João José Alves DIAS. Lisboa: Ed. Presença, 1998, p. 190.

${ }^{77}$ Adiante referirei alguns desses conflitos.
} 
lhes proporcionar os meios necessários para levar avante grandes explorações como era o caso das granjas ${ }^{78}$, ou que laboravam em moinhos, os quais proporcionavam, durante todo o ano, desperdícios de cereal capazes de alimentar vários suínos, podiam manter piaras bem consideráveis. Na verdade, era precisamente a uns ${ }^{79}$ e a outros ${ }^{80}$ daqueles foreiros que os monges pediam, como foragem, isto é, como um pagamento suplementar e por isso sem grande relevância no conjunto dos foros, duas marrãs ou uma marrã e um porco.

Com efeito, se por toda a parte, como atrás ficou dito, os espaços florestais eram densamente povoados de porcos em pastagem, ao menos durante o tempo da montanheira, os que revestiam as terras de Alcobaça não fugiam a esta regra. Nem seria lógico que fugissem. Abundando o sobreiro por todas aquelas matas, mesmo que não em dominância e sabendo-se como uma boa daquelas árvores podia produzir, ao menos em ano farto, tão grande quantidade de landes ${ }^{81}$; sendo esta essência, nas matas da região, acompanhada por outras também produtoras de bons frutos como a castanha, o melhor de $\operatorname{todos}^{82}$, a bolota de azinho ${ }^{83}$, a lande do carvalho e do carrasco ${ }^{84}$; sendo

\footnotetext{
${ }^{78}$ Como se sabe e como acontecia por todo o lado, durante a época aqui abordada quase todas as granjas deste como de outros mosteiros estavam emprazadas a particulares. Eram esses que pagavam os foros e as miunças mais elevados.

${ }^{79}$ TT, O. Cist., Alc., $2^{a}$ inc., mç. 46, $\mathrm{n}^{\circ} 1198$; mç. 86 , doc. s/nº ;v. 15, fol. 82-82v; lv. 136, fol. 22-22v, $102-103 \mathrm{v}$; lv. 183 , fol. $82 \mathrm{v}-83,144 \mathrm{v}-145$.

${ }^{80}$ TT, O. Cist., Alc., $2^{a}$ inc., mç. 86 , doc. $\mathrm{s} / \mathrm{n}^{\mathrm{o}} ; 1^{a}$ inc., mç. $37, \mathrm{n}^{\mathrm{o}} 32$.

${ }^{81}$ Numa carta régia de D. Afonso V diz-se que num bom sobral antigo, em termo de Évora, havia muitos sobreiros que produziam, cada um deles, um moio de lande e mais, podendo o sobral engordar quinhentos a seiscentos porcos por ano (HISTÓRIA FLORESTAL, aquícola e cinegética. Colectânea de documentos existentes no Arquivo Nacional da Torre do Tombo. Chancelarias Reais. Ed. Carlos Manuel L. Baeta Neves, vol. II (1439-1481). Lisboa: Ministério da Agricultura, Comércio e Pescas - Direcção-Geral das Florestas, 1982, pp. 117-118). É certo que em Évora, como por todo o Alentejo, vegetavam os sobreiros em terreno de sua eleição mas, ainda assim, é este um bom indício para aquilatar da sua excelente produtividade.

${ }^{82}$ Dada a importância do castanheiro na alimentação humana da época (veja-se, por exemplo, GONÇALVES, Iria - "A árvore na paisagem rural do Entre-Douro-e-Minho". in Por terras de EntreDouro-e-Minho com as inquirições de Afonso III. Porto: CITCEM - Faculdade de Letras da Universidade do Porto - Ed. Afrontamento, 2012, pp. 56-58); dado que não eram estes os espaços da sua primeira escolha, uma vez que preferia o clima mais húmido das terras altas do Norte e os seus solos graníticos; sendo, nos coutos de Alcobaça, menos abundantes e precisando de maiores cuidados, a presença dos animais era aí mais controlada, mas isso não os impedia de entrar em alguns soutos - não em todos - a aproveitar os seus frutos.

${ }^{83}$ Também os frutos da azinheira podiam ser - e eram - utilizados na alimentação humana (veja-se o trabalho citado na nota seguinte).

${ }^{84}$ Joaquim Pedro Fragoso de SEQUEIRA ("Memória sobre as azinheiras, sovereiras e carvalhos da província do Alentejo...", pp. 257-264) numa apreciação qualitativa das bolotas começa pelas da azinheira, as mais ricas, passando depois para as do sobreiro, a terminar nas do carvalho, como sendo as
} 
todos esses frutos tanto do apreço do gado porcino e tão capazes de o engordar e melhorar as suas carnes, como atrás já ficou dito, era impossível que toda essa riqueza não fosse aproveitada. E era-o tanto quanto possível, não só pelos habitantes da terra, mas também por outros dos arredores mais ou menos distantes que até aqui deslocavam os seus animais. O único senão encontrava-se no facto de nem todos os anos proporcionarem uma excelente colheita de frutos, alternando entre anezas de safra e de contra-safra, com todos os transtornos que daí advinham. Todavia, sendo várias as espécies que compunham cada um destes arvoredos, como já ficou dito; estando o sobreiro em dominância em tantos deles ${ }^{85}$, como também já ficou dito e sendo esta espécie tão produtiva que pode dar três camadas de frutos e não apenas uma ${ }^{86}$; havendo, em regra, alternância entre azinheiras e sobreiros no que se refere aos respectivos anos de safra ${ }^{87}$; havendo ainda possibilidade de pastagem para os porcos, nos soutos ${ }^{88}$, embora estas formações fossem muito pequenas ${ }^{89}$ e por isso não admitissem, no seu interior, grandes piaras, haveria sempre para eles algum alimento, embora nos anos de contra-safra do sobreiro esse alimento pudesse ser bastante minguado e de inferior qualidade, porque reduzido sobretudo a folhas, raízes, fungos.

De qualquer modo, em todos os lugares onde foi possível quantificar os proventos aduzidos pela cobrança do montado eles revelaram-se muito importantes ${ }^{90}$. E se dentro

de menor qualidade para a engorda do gado porcino. Mas todas elas acabavam por ser bastante satisfatórias para o efeito.

${ }^{85}$ Uma cartografia das matas de Alcobaça foi feita por GONÇALVES, Iria - O património do mosteiro de Alcobaça..., p. 103. Aí se indicam, para cada uma delas, as respectivas dominantes.

${ }^{86}$ SEQUEIRA, Joaquim Pedro Fragoso de - "Memória sobre as azinheiras...", p. 264.

${ }^{87}$ SEQUEIRA, Joaquim Pedro Fragoso de - "Memória sobre as azinheiras...", p. 261.

${ }^{88}$ Aliás, eram os porcos os únicos animais admitidos à pastagem nos soutos (GONÇALVES, Iria - $O$ património do mosteiro de Alcobaça..., p. 267). Porém, talvez com excepção apenas de um deles, chamado, por antonomásia, de "mata coutada", todos incluíam sobreiros e carvalhos na sua formação (GONÇALVES, Iria - "Traços da paisagem rural nas terras de Alcobaça (séculos XIV-XV)". in Tarouca e Cister. Espaço, espírito e poder. Actas, Setembro 2002. Tarouca: Câmara Municipal de Tarouca, 2004, p. 386).

89 Também em outros lugares estas matas, com a dominância do castanheiro podiam ser muito pequenas, com vinte, quarenta, cinquenta exemplares, embora pudessem ser constituídas quase em exclusivo por aquela essência que, em vários casos, durante a época aqui em estudo, estava a ser enxertada, mesmo pela mata adentro (GONÇALVES, Iria - "Sobre o coberto arbóreo da Beira Interior nos finais da Idade Média". in Estudos em homenagem ao Professor Doutor José Amadeu Coelho Dias. Vol. I. Porto: Faculdade de Letras da Universidade do Porto, 2006, p. 332).

90 CORRAO, Pietro - "Per una storia del bosco e dell'incolto in Sicilia fra XI e XIII secolo". in ANDREOLLI, Buno; MONTANARI, Massimo (ed.) - Il bosco nel Medioevo. Bolonha: CLUEB, 1988, reimp. de 1990, p. 358; GRESSER, Pierre - "Nature et montant des recettes forestières du comté de Bourgogne au XIV ${ }^{\mathrm{e}}$ siècle d'après les comptes de gruerie”. in DESSERT, Andrée Corvol (ed.) - Les 
das terras de Alcobaça e na época aqui tratada, essa quantificação não foi possível, por carência de informações, para período um pouco mais tardio, embora ainda dentro da primeira metade do século XVI, também isso se verificou ${ }^{91}$.

\section{IV - A conflitualidade decorrente do montado}

Nas primitivas cartas de povoamento, como já atrás ficou dito, nada se estabelecera sobre o pagamento do montado e o facto ficou claramente reconhecido no chamado foral manuelino ${ }^{92}$. Por outro lado, como acabou de ficar dito, os frutos abundavam e escasseavam em anos alternados. Eram estes, mais o primeiro, bastante menos o segundo, os pontos de conflitualidade, dentro desta matéria, entre o mosteiro e as suas vilas.

A primeira pendência de que nos chegou notícia data de 1380 e opunha Aljubarrota ao mosteiro. Todavia, a questão das pastagens era apenas mais um ponto na lista de queixas que os moradores da vila diziam ter contra o abade e convento. Não era, sequer, a única no que se refere à exploração da mata, que envolveria também o uso da madeira para diversos fins, a recolha de lenha e de casca de algumas árvores. As questões foram resolvidas, em bloco, por sentença régia, após acordo entre as partes, que sancionou os antigos usos com algumas restrições e manteve o montado ${ }^{93}$.

Se alguma outra das vilas também se sentiu, na ocasião, lesada nos seus direitos e costumes, não nos chegou notícia, mas as queixas que no caso eram formuladas por Aljubarrota contra os anteriores abades - de que ficaram referidos os nomes de D. Frei Vicente e D. Frei Martinho - e que eram atribuídas à posse, por parte dos abades, da jurisdição, não deixariam de estender-se às demais vilas e de lesar os interesses estabelecidos dos seus moradores. E o certo é que alguns anos mais tarde - em 1388 Évora e Turquel apresentaram também uma longa lista de queixas, algumas bastante

forêts d'Occident du Moyen Âge à nos jours. Actes des XXIV es Journées internationales d'histoire de l'abbaye de Flaran. 6, 7, 8 septembre 2002. Toulouse: Presses Universitaires du Mirail, 2004, p. 17.

${ }^{91}$ PENTEADO, Pedro - "Rendas e fazendas do mosteiro de Alcobaça durante a comenda do infante D. Afonso (1530-1536)". in Actas Cister. Espaços. Territórios. Paisagens. Colóquio internacional, 16-20 de Junho de 1998, Mosteiro de Alcobaça. Vol. II - Economia e sociedade. Espiritualidade. Arquitectura. Lisboa: IPPA, 2000, p. 93.

${ }^{2}$ FORAIS MANUELINOS do reino de Portugal e do Algarve, Estremadura..., p. 149.

${ }^{93}$ TT, O. Cist., Alc., $2^{a}$ inc., mç. 62, no 6; lv. 12, fol. 36v-38v. 
próximas das que Aljubarrota anteriormente formulara. De novo, no que se refere ao assunto aqui em análise, os pontos em litígio foram o pagamento, que consideravam abusivo, do montado dos porcos, na base de um animal por vintena ou de, avaliados a dinheiro, uma libra por vinte ${ }^{94}$; a obrigatoriedade, ao menos para o ano em curso, de levarem os porcos ao Vimeiro e a Alcobaça, para aí serem montados; a proibição de colherem lande nas matas, sob pena de prisão, do pagamento de sessenta soldos, ou de perderem metade do que haviam apanhado, quando, anteriormente, essa actividade era livre $^{95}$.

O processo deve ter-se arrastado até 1391, altura em que chegaram a um acordo, firmado por carta de 16 de Janeiro, segundo o qual os criadores das duas vilas se comprometiam a pagar o montado nos termos em que o mosteiro o reclamava, ficando, no entanto, isentos de pagamento quando nos carvalhais não houvesse fruto. $\mathrm{O}$ acordo foi depois sancionado por D. João I, por carta de 11 de Abril do mesmo ano ${ }^{96}$.

Neste, como em outros pontos então em conflito, pouco adiantaram as gentes dos coutos. Aliás, só restam informações acerca daquelas três vilas e, aparentemente, todas as outras teriam aceitado as determinações do senhor sem se manifestarem.

O poder senhorial era forte e dificilmente os povos se lhe podiam opor com sucesso. Assim, durante vários anos tudo pareceu aquietado, na medida em que a documentação não nos traz ecos de confronto. Todavia, o descontentamento devia continuar latente, porque ressurgiu na década de trinta do século seguinte, centrado, especificamente, no montado dos porcos e generalizado a quase todo o couto ${ }^{97}$.

\footnotetext{
${ }^{94}$ Foi esta sempre, em Alcobaça, a base de tributação para o pagamento do montado dos porcos. Já ficou dito. Era, na verdade, um pesado imposto e os criadores tinham motivo para queixa, sobretudo tendo tido, anteriormente, as matas livres para a pastagem dos seus animais. E conheceriam, sem dúvida, o que se passava em outros lugares, onde tudo era mais favorável. Em Abrantes, por exemplo, sabe-se que a pastagem era livre para os residentes no concelho e os de fora só se as utilizassem sem licença é que estavam sujeitos, e em conceito de multa, a ser-lhes tomado um porco em cada vinte, "asy dos bons como dos que tais nom forem" ("O LIVRO DE POSTURAS da vila de Abrantes...", p. 81).

${ }^{95}$ TT, O. Cist., Alc., lv. 5, fol. 153-160v.

${ }^{96}$ Existem vários documentos deste processo: TT, O. Cist., Alc., $2^{a}$ inc., mç. $2, \mathrm{n}^{\circ} 62 ;$ mç. 64, $\mathrm{n}^{\mathrm{o}} 33 ; 1^{a}$ inc., mç. 35, $\mathrm{n}^{\circ} 28$; lv. 3, fol. 55-55v; lv. 12, fol. 2v-3v, 3v-4v.

${ }^{97}$ A grande ausente nesta circunstância foi a Pederneira, uma das vilas mais populosas dos coutos. Mas a Pederneira tinha cariz diferente das demais, até pela sua situação geográfica e pelas condições do terreno em que assentava e tinha à sua volta. Povoação costeira, debruçada sobre a abertura que comunicava com o mar a lagoa que levava o seu nome, rodeada de terrenos arenosos e pobres, tendo como mata de seu uso
} 
Em 1434, possivelmente em altura próxima daquela em que a pastagem dos suínos nas matas iria começar, as vilas fizeram entre si um acordo, comprometendo-se a recusar o pagamento do montado, sob pena de dez mil reais a solver pelas que não mantivessem o combinado. Entretanto, algo deve ter acontecido que não ficou registado, nem qualquer informação permite aventar hipóteses, porque a 29 de Novembro, longe ainda, por isso, de terminar o período da montanheira, o concelho de Santa Catarina, chamado a reunir por pregão público, perante o tabelião da vila e na presença dos procuradores do mosteiro, um do abade, então D. Frei Estêvão de Aguiar, e o outro do convento, reconhecem a contenda que havia entre eles e embora os seus homens continuassem a considerar-se agravados pela exigência daquele pagamento, mostraram-se interessados em chegar a um acordo para evitar maiores males futuros. Combinaram que cada uma das partes se louvasse em um juiz, que ambos ouvissem as razões de uns e outros e pronunciassem depois o seu veredicto do qual não haveria apelação. Foi julgado por eles que o mosteiro tinha direito a receber o montado. Assim sendo e de acordo com a letra do contrato anteriormente estabelecido nada mais havia a fazer. Os homens de Santa Catarina limitaram-se a pedir que o D. Abade os livrasse da pena em que haviam incorrido ao quebrar o contrato com os outros concelhos. Ou a pagasse por eles. Desta vez comprometiam-se a manter o que fora ajustado com o mosteiro, sob pena dupla da anterior: vinte mil reais ${ }^{98}$.

No dia 9 de Dezembro foram os concelhos de S. Martinho e Alfeizerão que estabeleceram igual acordo com o mosteiro $^{99}$ e no dia 14 do mesmo mês foram Maiorga, Salir do Mato, Cela, de novo Alfeizerão e Santa Catarina e ainda outros lugares não nomeados que lhes seguiram o exemplo ${ }^{100}$.

É possível, todavia, que estes acertos se referissem apenas ao ano em curso, embora a documentação seja omissa a esse respeito, pois a contenda continuava os seus trâmites

o pinhal que se prolongava para Norte até Leiria, com uma população que maioritariamente se dedicava às fainas do mar, a Pederneira era efectivamente, e sobretudo tratando-se do assunto aqui em causa, bastante diferente das demais vilas. $\mathrm{O}$ assunto passava-lhe bastante ao lado.

${ }^{98}$ TT, O. Cist., Alc., $2^{a}$ inc., mç. $58, \mathrm{n}^{\circ} 11 ;$ lv. 10, fol. $45 \mathrm{v}-46$.

${ }^{99}$ TT, O. Cist., Alc., $2^{a}$ inc., mç. 58, no 11; mç. 64, no 12; lv. 10, fl. 46v.

${ }^{100}$ TT, O. Cist., Alc., $2^{a}$ inc., mç. 64, $\mathrm{n}^{\circ} 13$. 
na corte e esperava sentença régia ${ }^{101}$, que só viria por mão de D. Duarte, em Março de $1436^{102}$.

Talvez por isso é possível que de novo, naquele ano, se esperassem recusas ao pagamento, porque o próprio abade se deslocou a Alfeizerão onde, mediante pregão público, mandou que quem trouxesse porcos nas matas aí os fosse apresentar durante a primeira semana de Janeiro, entre os dias dois e sete ${ }^{103}$.

No entanto, passados dois dias, era já notório que ninguém apareceria com os cerdos para efectuar o pagamento, pelo que D. Frei Estêvão de Aguiar enviou um seu emissário às matas para anunciar que seria cobrado "montado direito", isto é, de vinte porcos um, aos que por sua vontade os levassem a Alfeizerão, mas que seriam "quintados", isto é, tomados na base de um em cada cinco, aos que o não quisessem fazer ${ }^{104}$.

Se o abade pretendia deste modo obter um efeito dissuasório e obrigar os homens a cumprir o seu mandado, não o conseguiu, pelo menos até findar o prazo que ele próprio estabelecera. Mandou então os seus homens pelas matas para daí tirarem todos os porcos que encontrassem ${ }^{105}$. Então, sim, perante esta ameaça real, pelo menos alguns homens dirigiram-se a Alfeizerão para pagar o tributo ${ }^{106}$. Mas não todos e talvez não a maior parte, porque a 17 e 18 de Janeiro novo pregão foi lançado, mandando que todos daí a seis dias tirassem os porcos das matas, sob pena de lhes serem tomados por $\operatorname{perdidos}^{107}$.

Évora e Turquel não tinham entrado nesta demanda ${ }^{108}$, o que não quer dizer que o assunto estivesse a decorrer pacificamente entre eles e o mosteiro. Também os homens de Évora e Turquel se não apresentaram em Alfeizerão com os seus animais, pelo que o

\footnotetext{
${ }^{101}$ TT, O. Cist., Alc., $2^{a}$ inc., mç. 70, doc. s/nº.

102 TT, O. Cist., Alc., $2^{a}$ inc., mç. 26, no 666; lv. 3, fol. 21v-22, 22-23.

${ }^{103}$ Restam-nos os que foram lançados em Alfeizerão, Maiorga e Cela: TT, O. Cist., Alc., $2^{a}$ inc., mç. 29, n. ${ }^{\text {os }} 708,712,715$; lv. 12 , fol. $139 \mathrm{v}-140$.

104 TT, O. Cist., Alc., $2^{a}$ inc., mç. 70, doc. s/no; lv. 12, fol. $141 \mathrm{v}-142$.

105 TT, O. Cist., Alc., $2^{a}$ inc., mç. 70, doc. s/no ; lv. 12, fol. $142 \mathrm{v}-143 \mathrm{v}$.

106 TT, O. Cist., Alc., $2^{a}$ inc., mç. 70, doc. s/no ; lv. 12, fol. 142.

107 TT, O. Cist., Alc., $2^{a}$ inc., mç. 29, no 717; lv. 12, fol. 140v.

108 TT, O. Cist., Alc., $2^{a}$ inc., mç. 70, doc. s/nº.
} 
abade "estaua bem sanhoso" 109 . Mas a reivindicação destes concelhos era apenas o lugar onde teriam de dirigir-se, pois haviam pedido ao abade que fizesse cobrança nas granjas de Turquel ou Vimeiro ou em Santa Catarina, conforme era costume. Mas acabaram por reconhecer que "fezerom mujto grande mall e erro" e foram perdoados sem qualquer penalização ${ }^{110}$.

Possivelmente a sentença proferida por D. Duarte ${ }^{111}$ veio pôr termo ao conflito, na medida em que a documentação deixou de se ocupar do assunto. $\mathrm{O}$ montado continuou a ser exigido - e sem dúvida pago - nos termos em que o mosteiro o reivindicava e nesses mesmos termos ficou fixado no chamado foral novo ${ }^{112}$.

Não obstante a reivindicação sempre presente ao longo de todo este processo - o direito de pastagem sem pagamento de montado - ter tido um desfecho negativo, alguma coisa de favorável resultou para os moradores dos coutos. Um dos seus agravos - o principal, segundo o diploma quinhentista, embora a documentação só ligeiramente se lhe refira era o de serem obrigados a pagar montado todos os anos, mesmo quando os frutos escasseavam. Posto que este assunto era potencialmente lesivo dos interesses, ou dos monges, ou dos moradores, ficou estabelecido que o imposto seria pago em anos alternados, uma vez que também a abundante produção de fruto se verificava em anos alternados. Ficou, pois, estabelecido que o mosteiro escolheria o primeiro ano em que deveria receber o tributo, ficando o ano seguinte livre aos moradores, quer houvesse, ou não, montanheira. Desde que ambas as partes tivessem chegado à igualdade no que se refere à fruição do seu direito, a alternância podia ser mudada, mas essa mudança não poderia verificar-se com periodicidade inferior a seis $\operatorname{anos}^{113}$. E foi tudo o que os moradores do couto conseguiram. Longe iam os tempos em que as matas podiam ser livremente exploradas por todos.

O direito de montado estava, ao tempo, já firmemente instalado e desde há muito. Não havia como erradicá-lo, nem sequer minorá-lo. O senhor tinha nas suas mãos todos os

\footnotetext{
109 TT, O. Cist., Alc., lv. 12, fol. 141-141v.

110 TT, O. Cist., Alc., $2^{a}$ inc., mç. 70, doc. s/no; lv. 12, fol. $140 \mathrm{v}-141$.

111 TT, O. Cist., Alc., $2^{a}$ inc., mç. 26, no 666; lv. 3, fol. 21v-22, 22-23.

${ }^{112}$ FORAIS MANUELINOS do reino de Portugal e do Algarve, Estremadura, pp. 149-150.

${ }^{113}$ FORAIS MANUELINOS do reino de Portugal e do Algarve, Estremadura, p. 150.
} 
meios necessários para o manter e cuidar da sua aplicação de modo a não haver prejuízo nas receitas que ele deveria fazer entrar nos cofres da abadia.

\section{Referências Bibliográficas:}

\section{Fontes manuscritas}

Arquivo Nacional da Torre do Tombo (TT)

Ordem de Cister, Mosteiro de Santa Maria de Alcobaça

- livros 3, 5, 10, 12, 15, 136, 183, 212.

- $1^{a}$ incorporação, maços 32, 35, 37, 39, 42 .

- $2^{a}$ incorporação, maços 1, 2, 26, 29, 38, 46, 48, 49, 58, 62, 64, 70, 86.

\section{Fontes impressas}

ACTAS DE VEREAÇÃO de Loulé. Século XV. supl. de Al'-Ulyā, n. ${ }^{\circ} 10$. Loulé: Arquivo Histórico Municipal de Loulé, 2004.

CHANCELARIA DE D. AFONSO III. Ed. Leontina Ventura e António Resende de Oliveira. Liv. I, vol. 1. Coimbra: Imprensa da Universidade de Coimbra, 2006.

FERNANDES, Rui - Descrição do terreno ao redor de Lamego duas léguas [15311532]. Ed. crítica de Amândio Morais Barros. Lamego: Beira Douro, 2001.

FORAIS MANUELINOS do reino de Portugal e do Algarve conforme o exemplar do Arquivo Nacional da Torre do Tombo de Lisboa - Estremadura. Ed. por Luiz Fernando de Carvalho Dias. Lisboa: L. F. C. Dias, 1962. 
HISTÓRIA FLORESTAL, aquícola e cinegética. Colectânea de documentos existentes no Arquivo Nacional da Torre do Tombo. Chancelarias Reais. Ed. Carlos Manuel L. Baeta Neves, vol. II (1439-1481). Lisboa: Ministério da Agricultura, Comércio e Pescas - Direcção-Geral das Florestas, 1982.

LIVRO DA VEREAÇÃO de Alcochete e Aldeia Galega (1421-1422). Introdução, transcrição e notas de José Manuel Vargas. Alcochete: Câmara Municipal de Alcochete, 2005.

LIVRO DAS POSTURAS ANTIGAS. Leitura paleográfica e transcrição de Maria Teresa Campos Rodrigues. Lisboa: Câmara Municipal de Lisboa, 1974.

“LIVRO DAS POSTURAS ANTIGAS de Évora”. [Transcrição de] Ana Sesifredo, Fátima Farrica e Miguel Meira. in Posturas municipais portuguesas (séculos XIVXVIII). Ponta Delgada: Centro de Estudos Gaspar Frutuoso, 2012, pp. 27-116.

“O LIVRO DAS POSTURAS DA VILA de Abrantes de 1515”. Ed. com nota explicativa de J. Candeias Silva. in Abrantes - Cadernos para a história do município, 1 (1982), pp. 69-94.

POSTURAS DO CONCELHO de Lisboa (século XIV). Apresentação de Francisco José Veloso, leitura paleográfica, nótula e vocabulário de José Pedro Machado. Lisboa: Sociedade de Língua Portuguesa, 1974.

VEREAÇÕES DA CÂMARA Municipal do Funchal, vol. II, Primeira metade do século XVI. Ed. por José Pereira da Costa. Funchal: Secretaria Regional do Turismo e Cultura, 1998.

\section{Estudos}

ALFONSO ANTÓN, Isabel - La colonización cisterciense en la meseta del Duero. El dominio de Moreruela (siglos XII-XIV). Zamora: Instituto de Estudios Zamoranos Florián de Ocampo - Diputación Provincial de Zamora, 1986. 
ALMEIDA, Fortunato de - História da Igreja em Portugal. 2. ${ }^{a}$ ed., org. por Damião Peres, vol. IV. Porto-Lisboa: Portucalense Editora, 1971.

ARGENTE DEL CASTILLO OCAÑA, Cármen - La ganadería medieval andaluza. Siglos XIII-XVI (Reinos de Jaén y Córdoba). Jaén: Diputacón Provincial de Jaén, 1991.

BARBOSA, Pedro Gomes - Povoamento e estrutura agrária da Estremadura Central. Séc. XII a 1325. Lisboa: INIC, 1992.

BARROS, Henrique da Gama - História da administração pública em Portugal nos seculos XII $a X V .2^{\mathrm{a}}$ ed. org. por Torquato de Sousa Soares, t. IX. Lisboa: Livraria Sá da Costa, 1950.

BARUZZI, Marina; MONTANARI, Massimo - Porci e porcari nel Medioevo. Paesaggio, economia, alimentazione. Bolonha: Museo della Civilita Contadina, 1981.

BECK, Corinne - "Animal et vie quotidienne en France et en Italie d'après les vestiges ostéologiques (XI ${ }^{\text {ème }}-\mathrm{XV}^{\text {ème }}$ siècles)". in Le monde animal et ses representations au Moyen Âge, (XIe-XVe siècles). Actes du XVème Congrès de la Société des historiens médiévistes de l'enseignement supérieur public, Toulouse, 25-26 mai 1984. Toulouse: Publications de l’Université de Toulouse-Le Mirail, 1985, pp. 103-120.

BERTHE, Maurice - Famines et épidemies dans les campagnes navarraises à la fin du Moyen Âge, 2 vols., Paris: SFIED, 1984.

BIASOTTI, Mirella; ISETTI, Paola - 'L'alimentazione dall' osteologia animali in Liguria”. Archeologia medievale, 8 (1981), pp. 239-246.

BLOCH, Marc - Les caractères originaux de l'histoire rurale française. $2^{\mathrm{a}}$ ed., vol. I. Paris: Armand Colin,1953.

CABRAL, Francisco Caldeira; TELLES, Gonçalo Ribeiro - A árvore em Portugal. Lisboa: Assírio \& Alvim, 1999. 
CABRERA MUÑOZ, Emilio - "El bosque, el monte y su aprovechamiento en la España del Sur durante la Baja Edad Media”. in PÉREZ-EMBID, Javier (ed.) - La Andalucía medieval. Actas "I Jornadas de historia rural y medio ambiente" (Almonte, 23-25 Maio 2000). Huelva: Universidad de Huelva - Servicio de Publicaciones, 2002, pp. 249-272.

CARMONA RUIZ, María Antonia - La ganadería en el reino de Sevilla durante la Baja Edad Media. Sevilha: Diputación de Sevilla, 1998.

CASTRO, Armando de - A evolução económica de Portugal dos séculos XII a XV. Vol. I. Lisboa: Portugália Editora, 1964.

- "Montado". in SERRÃo, Joel (dir.) - Dicionário de História de Portugal. Vol. III. Lisboa: Iniciativas Editoriais, 1968, p. 100.

- "Pinhal de Leiria". in SERRÃo, Joel (dir.) - Dicionário de História de Portugal. Vol. III. Lisboa: Iniciativas Editoriais, 1968, pp. 385-386.

CHARBONNIER, Pierre - Une autre France. La seigneurie rurale en Basse Auvergne du XIVe au XVI $I^{e}$ siècle. Vol. I e II. Clermont-Ferrand: Publications de l'Institut d'Études du Massif Centrale - Faculté des Lettres et Sciences Humaines de l'Université de Clermond-Ferrand, 1980.

CLEMENTE RAMOS, Julián - "La ganadería porcina de Jarandilla de la Vera a mediados del siglo XV”. in FONSECA, Luís Adão; AMARAL, Luís Carlos; SANTOS, Maria Fernanda Ferreira (ed.) - Os reinos ibéricos na Idade Média. Livro de homenagem ao Professor Doutor Humberto Carlos Baquero Moreno. Vol. II. Porto: Livraria Civilização Editora, 2003, pp. 743-749.

- La economía campesina en la Corona de Castilla (1000-1300). Barcelona: Crítica, 2004. 
COELHO, Maria Helena da Cruz - O Baixo Mondego nos finais da Idade Média (Estudo de história rural). Vol. I. Coimbra: Imprensa Nacional - Casa da Moeda, 1989.

CONDE, Manuel Sílvio Alves - Uma paisagem humanizada. O Médio Tejo nos finais da Idade Média. Vol. I. Cascais: Patrimonia, 2000.

CORRAO, Pietro - "Per una storia del bosco e dell'incolto in Sicilia fra XI e XIII secolo". in ANDREOLLI, Buno; MONTANARI, Massimo (ed.) - Il bosco nel Medioevo. Bolonha: CLUEB, 1988, reimp. de 1990, pp. 349-369.

CORREIA, Clara Pinto - Portugal animal. Fotografias de António José Cidadão. Lisboa: Relógio D’Água, 2000.

DELORT, Robert - Les animaux ont une histoire. Paris: Seuil, 1984.

DÉMIANS D'ARCHIMBAUD, Gabrielle - Les fouilles de Rougiers (Var). Contribution à l'archéologie de l'habitat rural médiéval en Pays méditerranéen, Paris: CNRS, 1980.

DEVÈZE, Michel - La vie de la forêt française au XVI siècle. Vol. I. Paris: S.E.V.P.E.N., 1961.

DUBY, Georges - L'économie rurale et la vie des campagnes dans l'Occident médiéval (France, Angleterre, Empire, IX $-X V^{e}$ siècles). Essai de synthèse et perspectives de recherche. Vol. I. Paris: Aubier, 1962.

DURAND, Robert - Les campagnes portugaises Entre Douro et Tage aux XII et XIII siècles. Paris: Centre Culturel Portugais, 1982.

DUVAL-ARNOULD, Louis - "Les ressources de la forêt royale de Retz et leur place dans l'économie de l'abbaye de Longpont". in L'économie cistercienne. Géographie Mutations du Moyen Âge aux temps moderns. Publications de la Commission d'Histoire de Flaran, 3. Auch: Comité Départemental du Tourisme de Gers, 1983, pp. 189-196. 
FERNANDES, João Luís Jesus - O homem, o espaço e o tempo no Maciço Calcário Estremenho. O olhar de um geógrafo. Lisboa - Coimbra: Ed. Colibri - Faculdade de Letras da Universidade de Coimbra, 2000.

FRANCO, João do Amaral - "Carvalho", Verbo. Enciclopédia luso-brasileira de cultura. Vol. 4. Lisboa: Verbo, [1992], col. 1247-1249.

FRÍAS ZURITA, Victor - "El medio natural en una sociedad señorializada: composición, explotación y apropriación del inculto en la Catalunya del Noreste (siglos X-XIII)". in CLEMENTE RAMOS, Julián (ed.) - El medio natural en la España medieval. Actas del I congreso de ecohistoria e historia medieval. Cáceres: Universidad de Extremadura, 2001, pp. 277-299.

GALETTI, Paola - "Bosco e spazi incolti nel territorio piacentino durante l'Alto Medioevo". in ANDREOLLI, Bruno; MONTANARI, Massimo (eds.) - Il bosco nel Medioevo. Bolonha: Casa Editrice Clueb, 1990, pp. 199-221.

GONÇALVES, Iria - O património do mosteiro de Alcobaça nos séculos XIV e XV. Lisboa: FCSH-UNL, 1989.

- "Traços da paisagem rural nas terras de Alcobaça (séculos XIV-XV)". in Tarouca e Cister. Espaço, espírito e poder. Actas, Setembro 2002. Tarouca: Câmara Municipal de Tarouca, 2004, pp. 367-388.

- "Sobre o coberto arbóreo da Beira Interior nos finais da Idade Média". in Estudos em homenagem ao Professor Doutor José Amadeu Coelho Dias. Vol. I. Porto: Faculdade de Letras da Universidade do Porto, 2006, pp. 321-350.

- “A alimentação". in MATTOSO, José (dir.) - História da vida privada em Portugal. Vol. I - A Idade Média. Coord. por Bernardo Vasconcelos e SOUSA. Lisboa: Temas e Debates - Círculo de Leitores, 2010, pp. 226-259. 
- "A árvore na paisagem rural do Entre-Douro-e-Minho". in Por terras de EntreDouro-e-Minho com as inquirições de Afonso III. Porto: CITCEM - Faculdade de Letras da Universidade do Porto - Ed. Afrontamento, 2012, pp. 49-84.

GRAND, Roger; DELATOUCHE, Raymond - L'agriculture au Moyen Âge. De la fin de l'Empire romain au XVI siècle. Vol. II, de SAVOY, Émile (dir.) - L'agriculture à travers les âges. Paris: Ed. de Boccard, 1950.

GRESSER, Pierre - "Nature et montant des recettes forestières du comté de Bourgogne au XIV ${ }^{\mathrm{e}}$ siècle d'après les comptes de gruerie". in DESSERT, Andrée Corvol (ed.) Les forêts d'Occident du Moyen Âge à nos jours. Actes des XXIVes Journées internationales d'histoire de l'abbaye de Flaran. 6, 7, 8 septembre 2002. Toulouse: Presses Universitaires du Mirail, 2004, pp. 13-38.

GUADALAJARA SOLERA, Simón - Lo pastoril en la cultura extremeña. Cáceres: Institución Cultural El Brocense, 1984.

HERCULANO, Alexandre - História de Portugal desde o começo da monarquia até ao fim do reinado de Afonso III. Ed. crítica de José MATTOSO, vol. IV. Lisboa: Livraria Bertrand, 1980.

HIGOUNET, Charles - "Les forêts de l'Europe Occidentale du V $\mathrm{V}^{\mathrm{e}}$ au XI $\mathrm{XI}^{\mathrm{e}}$ siècle". in Paysages et villages neufs du Moyen Âge. Bordéus: Fédération Historique du Sud Ouest, 1975, pp. 37-62.

KLEIN, Julius - La Mesta. Estudio de historia económica espanhola. 1273-1836. [3 ${ }^{\mathrm{a}}$ ed.]. Madrid: Alianza Editorial, 1981.

LAUTENSACH, Hermann - "A cobertura vegetal". in RIBEIRO, Orlando; LAUTENSACH, Hermann - Geografia de Portugal. Org., comentários e actualização por Suzanne DAVEAU. Vol. II, O ritmo climático e a paisagem. Lisboa: Ed. João Sá da Costa, 1988, pp. 539-575. 
MARTÍN GUTIÉRREZ, Emilio - Paisajes, ganadería y medio ambiente en las comarcas gaditanas. Siglos XIII al XVI. Cadiz: Universidad de Cadiz - Servicio de Publicaciones, 2015.

MAZZI Maria Serena; RAVEGGI, Sergio - Gli uomini e le cose nelle campagne fiorentine del Quattrocento. Florença: Olschki, 1983.

MONTANARI, Massimo - "Gli animali e l'alimentazione umana". in L'uomo di fronte al mondo animale nell'Alto Medioevo. XXXI Settimani di studi del Centro Italiano di Studi sull' Alto Medioevo. Tomo I. Spoleto: Centro italiano di studi sull'alto medioevo, 1985, pp. 619-663.

- Alimentazione e cultura nel Medioevo. Roma - Bari: Editiri Laterza, 1988.

- "Dal bosco alla stalla. Il maiale nel Medioevo" in Uomini, terre, boschi nell'Occidente medievale. Catania: Cooperativa Universitaria Catanese di Magistero, 1992, pp. 173-182.

- "Estruturas de produção e sistemas alimentares". in MONTANARI, Massimo; FLANDRIN, Jean-Louis (dir.) - História da alimentação.Vol. 1 - Dos primórdios à Idade Média. Trad. de Maria da Graça Pinhão. Lisboa: Terramar, 1998, pp. 251-259.

NATIVIDADE, Joaquim Vieira - A região de Alcobaça. Algumas notas para o estudo da sua agricultura, população e vida rural. Obras várias. Vol. I. Alcobaça: s.n., s. d.

NATIVIDADE, Joaquim Vieira; MACEDO, Jorge Borges - "As instituições e as técnicas na história regional”. in SILVA, Carlos da, ALARCÃO, Alberto; CARDOSO, António Poppe Lopes - A região a Oeste da Serra dos Candeeiros. Estudo económicoagrícola dos concelhos de Alcobaça, Nazaré, Caldas da Rainha, Óbidos e Peniche. Lisboa: Fundação Calouste Gulbenkian - Centro de Estudos de Economia Agrária, 1961, pp. 63-95. 
PENTEADO, Pedro - "Rendas e fazendas do mosteiro de Alcobaça durante a comenda do infante D. Afonso (1530-1536)". in Actas Cister. Espaços. Territórios. Paisagens. Colóquio internacional, 16-20 de Junho de 1998, Mosteiro de Alcobaça. Vol. II Economia e sociedade. Espiritualidade. Arquitectura. Lisboa: IPPA, 2000, pp. 89-98.

PÉREZ-EMBID, Javier - "El Císter hispano y la ganadería”. in ARÍZAGA BOLUMBURU, Beatriz et alii (ed.) - Mundos medievales: espacios, sociedades y poder. Homenaje al Profesor José Ángel García de Cortázar y Ruiz de Aguirre.T. II. Santander: PUbliCan - Ediciones de la Universidad de Cantabria, 2012, pp. 1769-1785.

REDON, Odile - "Les usages de la viande en Toscanie au XVI" siècle". in Manger et boire au Moyen Âge. Actes du colloque de Nice (15-17 octobre 1982). T. 2 - Cuisine, manières de table, régimes alimentaires. Nice: Publications de la Faculté des Lettres et de Sciences Humaines de Nice, 1984, pp. 121-130.

RIBEIRO, Orlando - Portugal, o Mediterrâneo e o Atlântico. Esboço de relações geográficas. $2^{\text {a }}$ ed. Lisboa: Sá da Costa, 1963.

- "O manto vegetal”. in RIBEIRO, Orlando; LAUTENSACH, Hermann - Geografia de Portugal. Org., comentários e actualização por Suzanne DAVEAU. Vol. II, O ritmo climático e a paisagem. Lisboa: Ed. João Sá da Costa, 1988, pp. 577-584.

RODRIGUES, Ana Maria Seabra de Almeida - "A produção agro-pecuária". in SERRÃO, Joel; MARQUES, A. H. de Oliveira (dir.) - Nova História de Portugal. Vol. V - Portugal do Renascimento à crise dinástica. Coord. por João José Alves DIAS. Lisboa: Ed. Presença, 1998, pp. 165-181.

SANTIARD, Marie-Thérèse - "La glandée dans les forêts ducales au XIV siècle d'après les comptes de gruerie”. Annales de Bourgogne XLVI (Out.-Dez. 1974), pp. 193-234.

SCLAFERT, Thérèse - Cultures en Haute Provence. Deboissement et pâturage au Moyen Âge. Paris: S.E.V.P.E.N., 1959. 
SEQUEIRA, Joaquim Pedro Fragoso de - "Memória sobre as azinheiras, sovereiras e carvalhos da província do Alentejo, onde se trata da sua cultura, e usos, e dos melhoramentos, que no estado actual podem ter". in Memórias económicas da Academia Real das Ciências de Lisboa, para o adiantamento da cultura, das artes e da indústria em Portugal e suas conquistas (1789-1815). t. II, dirig. por José Luís CARDOSO. Lisboa: Banco de Portugal, 1991, pp. 253-271.

SILVA, Carlos da, ALARCÃO, Alberto; CARDOSO, António Poppe Lopes - A região a Oeste da Serra dos Candeeiros. Estudo económico-agrícola dos concelhos de Alcobaça, Nazaré, Caldas da Rainha, Óbidos e Peniche. Lisboa: Fundação Calouste Gulbenkian - Centro de Estudos de Economia Agrária, 1961.

TRINDADE, Maria José Lagos - "A vida pastoril e o pastoreio em Portugal nos séculos XII a XVI". in Estudos de história medieval e outros. Lisboa: História \& Crítica, 1981, pp. 1-95.

VICENTE, Maria da Graça - Povoamento e propriedade entre o Zêzere e o Tejo (séc. XII-XIV). Lisboa: Ed. Colibri, 2015.

\section{COMO CITAR ESTE ARTIGO}

\section{Referência electrónica:}

GONÇALVES, Iria - "Para o estudo de um direito senhorial nas terras medievais de Alcobaça: o montado dos porcos". Medievalista 22 (Julho-Dezembro 2017). [Em linha] [Consultado dd.mm.aaaa]. Disponível em http://www2.fcsh.unl.pt/iem/medievalista/MEDIEVALISTA22/goncalves2202.html ISSN 1646-740X. 


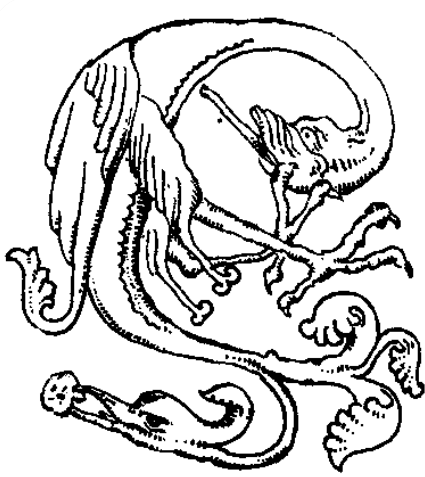

